\title{
PRODUÇÃO E PRODUTIVIDADE NA AGRICULTURA DO ESTADO DE GOIÁS, 1995
}

\section{SEBASTIÃO MARCOS PEREIRA}

Economista

Orientador: Prof. Dr. PAULO FERNANDO CIDADE DE ARAÚJO

Dissertação apresentada à Escola Superior de Agricultura "Luiz de Queiroz", Universidade de São Paulo, para a obtenção do título de Mestre em Ciências, Área de Concentração: Economia Aplicada.

PIRACICABA

Estado de São Paulo - Brasil

Fevereiro - 2001 
Dados Internacionais de Catalogação na Publicação (CIP) DIVISÃO DE BIBLIOTECA E DOCUMENTAÇÃO - Campus "Luiz de Oueiroz"/USP

\author{
Pereira, Sebastião Marcos \\ Produção e produtividade na agricultura do Estado de Goiás, 1995 / Sebastião \\ Màrcos Pereira. - Piracicaba, 2001. \\ $80 \mathrm{p}$. \\ Dissertação (mestrado) - - Escola Superior de Agricultura Luiz de Queiroz, 2001. \\ Bibliografia. \\ 1. Agricultura 2. Desenvolvimento agricola 3. Função de produção 4. Produção \\ agrícola 5. Produtividade agricola I. Título \\ CDD 338.1
}

Permitida a copia tota ou parcial deste documento, desde que citada a fonte- Oe autor 
Aos meus pais,

\section{OFEREÇO}

A minha Esposa

DEDICO 


\section{AGRADECIMENTOS}

Primeiramente, gostaria de agradecer a Deus pela vida, pelos momentos de alegria, pelas vitorias e derrotas.

Agradeço à Escola Superior de Agricultura "Luiz de Queiroz", pela oportunidade e a Universidade Federal de Viçosa pelo incentivo.

Ao professor Paulo Fernando Cidade de Araújo pelo conhecimento, pela amizade, pelos ensinamentos para a vida e pela paciência. Por tudo isso, tenho o prazer de chamá-lo mestre.

Agradeço também ao Profs. Ricardo Shirota e Alexandre Lahóz Mendonça de Barros pelas críticas e sugestões nas diferentes fases desta pesquisa.

Aos funcionários do Departamento de Economia, Administração e Sociologia da ESALQ/USP, meu reconhecimento maior e em especial, à Helena Aparecida Cardoso pelo seu eficiente trabalho editorial desta dissertação.

A minha esposa e família, pela compreensão e incentivo. 


\section{SUMÁRIO}

Página

SUMÁRIO iv

LISTA DE TABELAS ...................................................................... vii

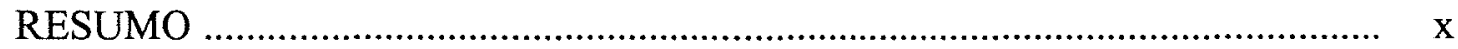

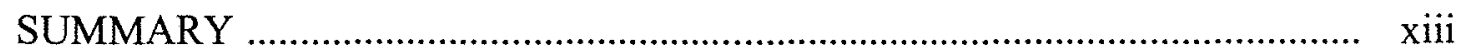

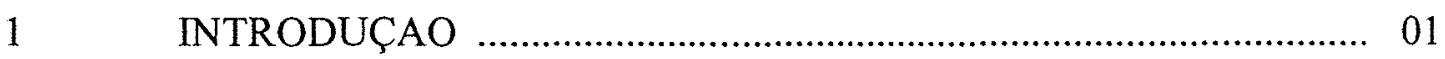

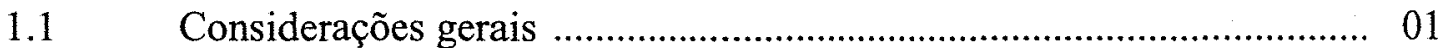

O problema e sua importância ....................................................... 03

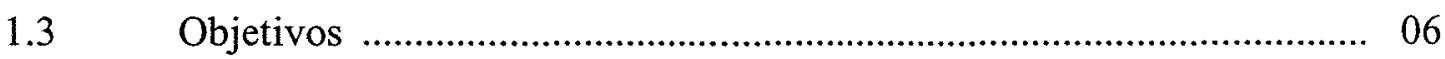

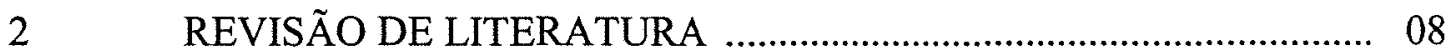

2.1 Breve retrospectiva da agricultura do Estado de Goiás..................... 08

Alocação e produtividade dos fatores ............................................ 14

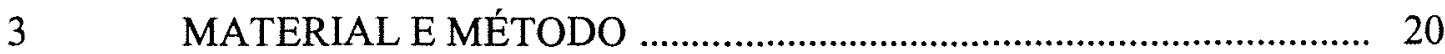

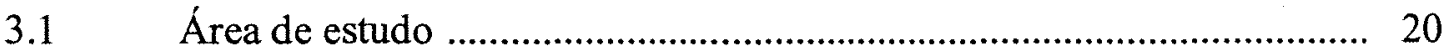

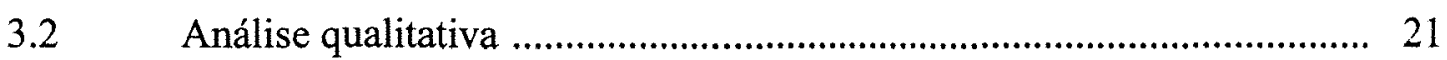


Página

3.3 Análise quantitativa e modelo econométrico

3.4 Variáveis da função de produção 25

4 RESULTADOS E DISCUSSÃO 26

4.1 Evolução das principais variáveis agrícolas 26

4.1.1 Produção agrícola e pecuária 28

4.1.2 Crescimento da área agrícola 34

4.1.2.1 Utilização de áreas com lavouras permanentes e temporárias 35

4.1.2.1.1 Principais culturas temporárias no Estado de Goiás 36

4.1.2.2 Utilização de terras com pastagens naturais e plantadas 40

4.1.2.2.1 Rebanho bovino no Estado de Goiás 42

4.1.3 Utilização de trabalho na agricultura 44

4.1.4 Produtividade da terra 49

4.1.5 Nível de investimentos na agricultura 49

4.1.6 Evolução da área cultivada por trabalhador e mecanização agrícola

4.2 Educação e crescimento da população brasileira e goiana de 1970 a 1991 56

4.3 Metafunção de produção para o Estado de Goiás 59 
4.3.1 Produtividade marginal dos fatores de produção nas microrregiões do Estado ........................................................................ 63

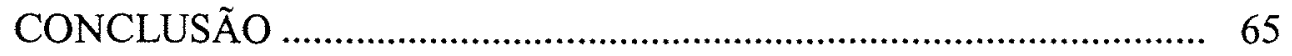

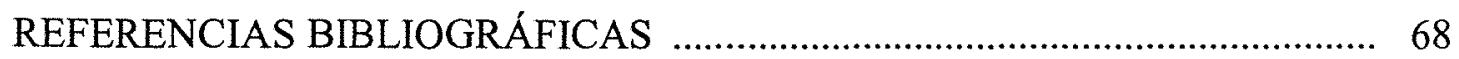

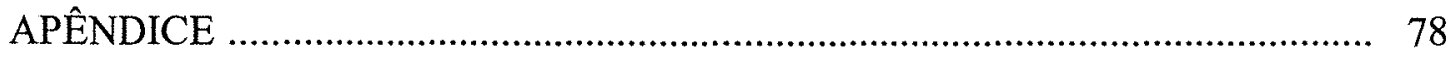




\section{LISTA DE TABELAS}

Página

1. Situação das principais variáveis agrícolas do Estado de Goiás, 1970-1995

2. Proporção do número e da área dos estabelecimentos, por grupos de área total, Goiás, 1970 - 1995.

3. Rendimento das principais lavouras, segundo os Censos Agropecuários, Goiás, 1985 - 1995

4. Comportamento da produção, área total, trabalho e tratores agrícolas, da produtividade da terra e do trabalho na agricultura, e da relação área-homem no Estado de Goiás, 1970 - 1995

5. Evolução da produção, área total, trabalho e tratores agrícolas, da produtividade da terra e do trabalho na agricultura, e da relação área-homem no Estado de Goiás, 1970 - 1995

6. Valor real da produção agrícola brasileira e goiana, 1970 - 1995

7. Evolução dos preços reais dos principais produtos agrícolas no Estado de Goiás, 1970 - 1995

8. Evolução do índice de quantidade das principais lavouras no Estado de Goiás, 1970 - 1995 
9. Valor real da produção (IGP-DI, FGV), em mil reais de 1995, das principais culturas do Estado de Goiás, 1970 - 1995

10. Variáveis referentes a utilização potencial das terras pela agricultura do Estado de Goiás, 1970 - 1995

11. Porcentagem da área agricultável destinada a lavouras permanentes e temporárias no Estado de Goiás, 1970 - 1995

12. Produção, área colhida e produtividade do arroz no Estado de Goiás, 1970 - 1995.

13. Produção, área colhida e produtividade de feijão no Estado de Goiás, 1970 - 1995 . 38

14. Produção, área colhida e produtividade de milho no Estado de Goiás, 1970 - 1995 . 38

15. Produção, área colhida e produtividade de soja no Estado de Goiás, $1970-1995$.

16. Participação das áreas com pastagens naturais e plantadas na área total agricultável do Estado de Goiás, 1970 - 1995

17. Evolução do rebanho bovino nacional e goiano, $1970-1995$.

18. Total de bovinos por microrregião em Goiás, 1970 - 1980

19. Total de bovinos por microrregião em Goiás, $1985-1995$

20. Microrregiões e Municípios que mais empregaram pessoas na agricultura do Estado de Goiás, 1970 - 1995 . 
21. Quantidade de homens e mulheres empregados no setor agrícola do Estado de Goiás, 1970 - 1995

22. Porcentagens de menores no emprego agrícola do Estado de Goiás, $1970-1995$

23. Comparação da utilização de Trabalho infantil na agricultura brasileira e goiana, $1970-1995$ 48

24. Valor e evolução do investimento e da produção da agricultura, em mil reais, Brasil, 1970 - 1995

25. Valor e evolução do investimento e da produção da agricultura, em mil reais, Estado de Goiás, 1970 - 1995 51

26. Quantidade de tratores empregados na agricultura do Brasil e do Estado de Goiás, 1970 - 1995

27. Quantidade de tratores utilizados na agricultura de Goiás. 1970

$-1995$

28. População brasileira e população de cinco anos ou mais alfabetizada no Brasil, 1970 - 1991 56

29. População e nível de alfabetização em Goiás, 1970 - 1991 57

30. Evolução da população rural e urbana e nível de alfabetização no Estado de Goiás, 1970 - 1991 58

31. Coeficientes de regressão e valores do teste " $t$ " para as variáveis da metafunção de produção 
Página

32. Matriz de correlação entre as variáveis na forma logarítmica da metafunção de produção para o Estado de Goiás, 1995/96.

33. Produtividade marginal nas principais microrregiões do Estado de Goiás. 1995 ..... 


\title{
PRODUÇÃO E PRODUTIVIDADE NA AGRICULTURA DO ESTADO DE GOIÁS, 1995
}

\author{
Autor: SEBASTIÃO MARCOS PEREIRA \\ Orientador: Prof. PAULO FERNANDO CIDADE DE ARAÚJO
}

\section{RESUMO}

Este trabalho analisa as relações de produção e produtividade no Estado de Goiás, do ponto de vista qualitativo e quantitativo, no período 1970-1995. A análise quantitativa refere-se ao ano de 1995, com base nos dados de 170 municípios divulgados pelo IBGE no Censo Agropecuário. O modelo econométrico utilizado é uma meta-função de produção, do tipo Cobb-Douglas, em que a variável dependente é o valor bruto da produção agropecuária. As variáveis independentes especificadas são: força de trabalho, capital em máquinas, terra com lavouras, terra com pastagens, insumos modernos agrícolas, insumos modernos na pecuária e escolaridade no meio rural.

A análise qualitativa mostra que, nesse período, a evolução do setor agropecuário de Goiás pode ser dividida em duas fase. A primeira vai de 1970 até 1985, com o crescimento extensivo e ritmo acelerado do produto. A partir de 1985, começou a ocorrer progressiva restruturação do processo produtivo na busca de ganhos de produtividade dos fatores. As decisões de produzir foram então influenciadas pelas culturas de maior rentabilidade (soja e milho, por exemplo); na pecuária de corte ocorreu melhoria nas práticas de manejo. Acelerou-se a 
substituição de trabalho por capital e a estrutura fundiária começou a dar sinais de concentração da terra. Como resultante desse segundo cenário, observou-se o crescimento setorial a taxas modestas, culminando, em 1995, com taxa negativa de crescimento.

$\mathrm{Na}$ análise quantitativa, o modelo ajustado apresenta as relações esperadas de valor da produção e uso de fatores produtivos convencionais; a variável educação também apresenta efeito direto positivo sobre a variável dependente, embora com menor confiabilidade estatística. Além disso o modelo sugere elevado poder explicativo do valor do produto agropecuário, aproximadamente $90 \%$. E as variáveis de maior elasticidade parcial de produção são o estoque de capital e os insumos modernos. Assim, esses dois fatores poderiam exercer maior influência sobre o crescimento do produto agropecuário. Mas, as diferenças regionais de produtividade dos fatores devem ser consideradas pois as políticas agrícolas, se aplicadas indistintamente, não contribuirão para amenizar as diferenças entre as microrregiões do Estado e, desse modo, comprometerão o desenvolvimento rural, em seu sentido mais amplo. 


\title{
ANALISYS OF AGRICULTURAL OUTPUT AND FACTOR PRODUTIVITY IN THE STATE OF GOIAS, BRAZIL
}

\author{
Author: SEBASTIÃO MARCOS PEREIRA
}

Adviser: Prof. PAULO FERNANDO CIDADE DE ARAÚJO

\section{SUMMARY:}

This paper aims to study the production and the factor productivity relationships in the agricultural sector of the State of Goias during 1970-1995 period. The quantitative analysis refers to the 1995 calendar year, and is based on the Agricultural Census data. The econometric model is a Cobb-Douglas metaproduction function, with 170 county observations. The selected variables of the were: gross value of agricultural output, as dependent variable; and, capital, labor, land, modern operational inputs in crops and in cattle raising, and rural education, as independent variables.

The findings of the qualitative analysis suggest that the evolution of the growth process of agriculture can be divided in two different stages. The first one, from 1970 to 1985, may be interpreted as an extensive type of aggregate performance with very high annual growth rates. The second, from 1985 to 1995 , may be looked as a progressive change in the productive process based on total factor productivity gains. During this first stage, soybeans and corn assumed the top 
positions among the produced crops, and major changes were also observed in the factor shares, with the substitution of capital for labor in production functions.

The econometric model shows positive relationships between gross output value and conventional factors of production, labor, capital, land and modern inputs. The direct effect of education is also positive, but only shows a poor statistical reliance. It also indicates significant differences in marginal factor productivity estimates for major agricultural regions of the State. 


\section{INTRODUÇÃO}

\subsection{Considerações gerais}

Pretende-se, neste trabalho, analisar a produção e produtividade agrícola do Estado de Goiás, bem como identificar eventuais pontos de estrangulamento que desestimulam a modernização do setor.

A agricultura é uma atividade em que produtores e trabalhadores encontramse em contato permanente com a natureza na busca de melhores condições de vida. Este contato estreito entre homem e natureza sofre profundas alterações com o desenvolvimento da agricultura. Uma explicação parcial para o fato é encontrada no incremento de produtividade via mecanização e/ou inovações químico-biológicas. A associação desse argumento com a falta de investimentos públicos torna complicada a situação da agricultura e das cidades mais populosas em muitos países. Neste contexto, surge a necessidade de modernizar o meio rural para evitar que a pobreza rural se transforme em pobreza urbana.

No processo de modernização da agricultura, o enfoque da política econômica deve voltar-se principalmente para o progresso técnico, não tendo em vista o crescimento extensivo do produto bruto (Pastore et al., 1976).

É verdade que a participação do setor agrícola no total da economia diminui à medida que os países crescem ou se desenvolvem. Entretanto, deve-se ressaltar que essa queda não implica perda de importância social e econômica da agricultura. 
O crescimento da indústria e do setor de serviços oferece uma gama de bens em maior quantidade e, muitas vezes, de maior valor adicionado, aumentando a participação desses setores na formação do Produto Interno Bruto (PIB). Esta diversificação de bens e serviços tem como conseqüência o aumento da importância estratégica do setor agrícola, pois há necessidade de manter a população alimentada, gerar divisas, fornecer mão-de-obra, matérias-primas e capitais para os demais setores. ${ }^{1}$

Porém, o agricultor não detém o pleno controle sobre os meios de produção. A oferta agrícola é influenciada por diversos fatores aleatórios. Um exemplo disso, está no fato de a produção utilizar insumos vivos, necessitando, portanto, de condições de clima, temperatura, ou seja, de condições naturais para se desenvolver. Esta situação tira do agricultor o planejamento sobre o que e quanto produz. Por este motivo, também, as oscilações de preços e renda são mais freqüentes na agricultura.

No tempo, os agricultores podem ser seletivos sobre o que produzir, escolhendo aqueles produtos onde a flutuação de preços é menor e maiores são os ganhos de produtividade. Com isso, a oferta agrícola pode ser composta por produtos que vão atender a um determinado setor da economia, provavelmente o externo, no caso de economias abertas. Assim, o setor urbano pode ser prejudicado, pois no curso do processo de desenvolvimento a população nas cidades tende a aumentar. $O$ poder aquisitivo de boa parte desta população é baixo e fatia significativa dos salários é destinada à compra de alimentos. Este cenário é problemático, pois à medida que a população urbana cresce, o aumento da demanda pressiona os preços dos alimentos e o custo de vida.

Ao oferecer alimentos baratos, a agricultura transfere renda e bem-estar para os outros setores da economia. As nações desenvolvidas tiveram, nos estágios iniciais de desenvolvimento, a agricultura como principal setor. Ao exportar excedentes de alimentos e matérias-primas, o setor obteve receitas que impulsionaram os demais setores da economia. Com o crescimento econômico, normalmente ocorre modificação

\footnotetext{
${ }^{1}$ Veja maiores detalhes sobre o papel da agricultura no desenvolvimento em Araújo e Schuh (1998).
} 
na pauta de exportação e os países, para continuar o processo de crescimento, precisam obter divisas pela exportação de produtos de maior valor adicionado.

Para que a agricultura cumpra o seu papel de gerar excedentes de produto, de fatores e de mercado (Kuznets, 1964), o setor deve priorizar o incremento da produtividade total dos fatores. É neste contexto que se coloca ou deve ser colocada a agricultura do Estado de Goiás. A cada ano, aumenta sua importância no cenário nacional e cresce sua participação no PIB nacional. Segundo dados da Secretaria de Planejamento e Desenvolvimento do Estado de Goiás - SEPLAN - GO, 1999, o PIB estadual aumentou 32,73\%, de 1993 a 1997, enquanto o PIB do Brasil cresceu 21,94\%. Na safra 1996/97, o PIB agrícola do Estado cresceu, em termos reais, 7,5\% contra 0,31\% do PIB agrícola nacional.

\subsection{O Problema e sua importância}

A oferta agrícola, conforme visto, deve ser crescente para atender as necessidades de desenvolvimento da sociedade. Porém, Barbosa (1987) e Pereira (1996) salientam que a produção agropecuária leva certo tempo entre o planejamento da mesma e a colocação do produto no mercado. Segundo esses autores, mudanças externas à "porteira da fazenda", como por exemplo alteração no cenário macroeconômico do país, podem interferir na alocação dos fatores produtivos no campo. Argumentam, também, que as políticas governamentais são, em muitos casos, descompassadas no curto e longo prazo, bem como entre os setores que atingem.

Estas políticas provocaram a intervenção governamental na agricultura brasileira e goiana, principalmente, a partir da década de 60 . Na década de 70 , tornaramse maiores os esforços para a expansão da fronteira agrícola. A região de cerrados, aqui representada pelo Estado de Goiás, apresenta características peculiares (terras de baixa 
fertilidade) e por muito tempo consideradas inaptas ao cultivo agrícola, sofreu maciças inversões de capital e tecnologia. ${ }^{2}$

Porém, essa intervenção se deu de duas maneiras distintas. De um lado incentivava o crescimento da produção subsidiando-a através de linhas especificas de crédito. Por outro lado, arquitetava um cenário macro e microeconômico que extraia do setor renda e fatores para sustentar o crescimento da economia (Lopes, 1993).

Assim, a agricultura goiana, impulsionada pelos incentivos concedidos, cresceu a taxas superiores a $23 \%$ ao ano entre 1970 a 1980 . O mesmo não ocorreu no início da década de 80 . Com a mudança paulatina da política governamental de subsídios ao setor e com a manutenção dos cenários macroeconômicos prejudiciais ao desenvolvimento agropecuário, as taxas de crescimento do setor, em Goiás, foram modestas $(1,45 \%$ ao ano de 1980 a 1985). Este fato foi, também, detectado por Figueiredo (1996).

A situação piorara consideravelmente a partir de 1985. Planos econômicos foram implantados e substituídos. Houve congelamento de preços, forte descompasso da política de preços mínimos e subsídio à importação de alimentos. ${ }^{3}$

Já em 1990/92, o setor agropecuário experimenta a abertura comercial iniciada no governo Collor. Percebe-se, novamente, desacordo entre política geral e política agrícola. ${ }^{4}$ Num período, forte intervenção com a oferta agrícola ora suprindo as necessidades ora necessitando de importações. Noutro período, libera-se o comércio e coloca-se o produtor nacional a competir de igual com agricultores que, em muitos casos, têm seus produtos subsidiados nos países de origem. Ocorreu, também, como agravante deste problema, ao lado do bloqueio dos meios de pagamentos da sociedade como um todo e a correção dos indicadores financeiros em base diferenciada para os

\footnotetext{
${ }^{2}$ Maiores detalhes sobre as características fisiográficas dos cerrados estão em Cunha, et al. (1994, p. 14), e sobre sua rentabilidade, ver Oliveira (1985).

${ }^{3}$ Para Homem de Melo (1990) a agricultura deu sinais de recuperação mesmo com esse cenário desanimador.

${ }^{4}$ Ver Carvalho (1989).
} 
agricultores que realizaram empréstimos bancários. Os empréstimos foram corrigidos por um índice mais alto do que a capacidade de pagamento dos mutuários, ou seja, os juros tiveram correção de $84 \%$ enquanto o preço mínimo ficou muito defasado (Araújo et al., 1991).

A conseqüência dessas politicas ${ }^{5}$ foi o aumento das incertezas do mercado quanto a manutenção de crescimento dos setores produtivos, principalmente o agrícola. Além do mais, a agricultura moderna e, capitalizada, implantada em Goiás, demanda quantidade expressiva de recursos financeiros. Ao mesmo tempo, o risco dos investimentos em bens de capital torna-se elevado. Isto constitui sério problema para os agricultores, principalmente para aqueles cujo acesso à informação não é privilegiado.

Como resultado desse cenário, a safra agrícola de 1995/96, ano censitário e de análise quantitativa nesta pesquisa, registrou uma queda dos principais indicadores agrícola. A produção agropecuária decaiu $3,38 \%$ a.a. em termos reais no período de 1985 a 1995.

O IBGE caracteriza tal safra como atípica. A criação do Plano Real provoca forte impacto sobre a agricultura. A quebra da inércia inflacionária tirou dos agricultores a ilusão monetária de ganhos nominais. Também, a safra 1994/95 foi relativamente grande resultando em queda de preços no mercado interno e desestímulo ao novo plantio. Houve, também, queda dos preços dos produtos agrícolas no mercado externo e valorização cambial que impulsionou a importação de alimentos e minguou as chances da exportação brasileira. O governo afastou-se das políticas de preços mínimos e de crédito rural ilimitado. Os excedentes agrícolas não foram adquiridos pelo governo e sim colocados no mercado causando queda ainda maior de preços internos. Com essas medidas, houve incerteza quanto ao plantio da próxima safra (1995/96) e os agricultores tornaram-se mais seletivos, voltando seus esforços para lavouras sobre as quais tinham domínio e maior apoio em termos de tecnologia, de insumos modernos e de alternativas

\footnotetext{
${ }^{5}$ Para Lemos (1996) o impacto da liberalização agrícola sobre o desenvolvimento regional é incerto. Percebe-se que o setor interno tem ineficiências que no longo prazo podem comprometer alguns subsetores.
} 
para financiamento e comercialização (Censo Agropecuário de Goiás, 1995). Vale destacar, porém que abertura econômica tornou mais barata a importação de insumos o que por certo teve efeito favorável, reduzindo custos.

A safra 1995/96 é o marco de uma nova fase na agricultura brasileira evidenciada pelo ajustamento dos fatores de produção em busca de ganhos de produtividade e com reduzida intervenção governamental.

Nas safras seguintes, praticamente o mesmo cenário econômico de 1995 preocupava os agricultores. Agroanalysis (1996), com referência à safra 1995/96, dizia que muitos agricultores que perderam seus tratores e terras, foram acusados, generalizadamente, de caloteiros e amargaram prejuízos consideráveis. Mesmo o governo solucionando, parcialmente, algumas questões como a securitização da dívida dos produtores em 1996/97 e a desvalorização cambial em 1999, persistem as expectativas sobre o setor quanto a manutenção das receitas e diminuição de custos.

Com relação aos custos de produção, Araújo et al. (1991) já se preocupavam com os mesmos deste 1991. Numa pesquisa realizada entre agricultores da região de Rio Verde, principal pólo agroindustrial do Estado de Goiás, perceberam que os mesmos tiveram problemas para saldar suas dívidas no mercado financeiro. Tornou-se, então, necessária uma realocação dos fatores produtivos para viabilizar o melhor desempenho econômico da agricultura no município. Por outro lado, o incremento de produtividade dos fatores de produção provocou o aumento da oferta agrícola e, a seguir, queda dos preços internos.

\subsection{Objetivos}

Neste quadro de referência, o presente estudo pretende analisar, em termos agregados, as relações de produção e produtividade na agricultura goiana. Objetiva também estimar e interpretar os níveis de produtividade das principais regiões agrícolas do Estado, à luz dos dados censitários de 1995. 
Especificamente, pretende-se:

$\mathrm{Na}$ análise qualitativa, identificar a evolução das principais características socioeconômicas do setor agrícola do Estado no período 1970-1995. Ênfase especial será atribuída aos seguintes tópicos:

- produção agrícola;

- crescimento da área agrícola;

- utilização de áreas com lavouras permanentes e temporárias;

- principais culturas temporárias no Estado de Goiás;

- utilização de terras com pastagens naturais e plantadas;

- rebanho bovino no Estado de Goiás;

- utilização de trabalho na agricultura;

- produtividade da terra;

- nível de investimento na agricultura;

- evolução da área cultivada por trabalhador e mecanização agrícola;

- educação e crescimento populacional;

- evolução da população brasileira e goiana; e,

- evolução da população e alfabetização rural e urbana em Goiás.

$\mathrm{Na}$ análise quantitativa, estudar alocação e produtividade dos fatores de produção, através do ajustamento de uma metafunção de produção no ano de 1995, com base em estatísticas do Censo Agropecuário, por município e analisar o efeito direto da educação e da extensão rural sobre a produção agropecuária. 


\section{REVISÃO DE LITERATURA}

\subsection{Breve retrospectiva da agricultura do Estado de Goiás}

As primeiras bandeiras chegaram ao território goiano no final do século XVII. Os objetivos dos bandeirantes eram a captura de indígenas e a procura de riquezas minerais. O ouro e o diamante, foram encontrados a partir de 1725 (Bertran, 1978 e Estevam, 1998). O modo de exploração baseou-se principalmente na lavra, com a utilização de pequeno contingente populacional e sem a formação de cidades. O colonizador procurava exaurir a lavra e transferir-se depois para outra. Neste processo, as bandeiras foram adentrando o interior das bacias hidrográficas da região, ao mesmo tempo que expulsavam ou colonizavam os indígenas.

A fundação de aldeias só ocorreu a partir do momento em que, para obter ouro e outros minerais, tornou-se preciso escavar as encostas de montanhas ou rios, exigindo para tanto uma infra-estrutura básica. A nova realidade gerou a necessidade de se ter uma agricultura de subsistência para garantir a vida "urbana" recém-criada. Neste sentido, o mesmo Bertran destaca que "a vida rural derivou da carência de subsistência em meio urbano".

A fase aurífera trouxe um contingente de escravos que já realizavam mineração em Minas Gerais. Entretanto, concluída esta fase, as pessoas se transferiram para outras localidades não se preocupando em desenvolver as regiões que habitavam.

No século XIX, a mineração já se encontrava em decadência e exercida como atividade secundária. A queda na produção mineral trouxe como conseqüência o êxodo da quase totalidade das pessoas interessadas apenas nas riquezas que o setor podia 
oferecer. À população permanente restou optar entre as atividades favorecidas pelos recursos naturais dos campos abertos e cerrados. A princípio a bovinocultura foi a opção predominante. Tal escolha se justificava pois, conforme Bertran (1978), o gado é preferivel em localidades de precária infra-estrutura de transporte.

O desenvolvimento da bovinocultura ocorreu de forma intensa no sul e sudoeste do Estado (por serem próximos do triângulo mineiro e de São Paulo). E no norte (atualmente norte do Estado do Tocantins) pela proximidade de Belém (devido ao ciclo da borracha) e do Maranhão.

A agricultura permaneceu, durante o século XIX, com características de agricultura tradicional. O aumento de área plantada ocorreu lentamente através do desmatamento das matas locais na busca de terras férteis. A baixa fertilidade das terras goianas e o alto custo da mão-de-obra constituíram fatores desestimulantes à atividade agrícola (Bertran, 1978).

No século XX, dois fatos foram fundamentais para o estabelecimento das condições necessárias ao crescimento da atividade agrícola goiana. Em primeiro lugar, destaca-se a construção de ferrovia transpondo o rio Paranaíba e ligando Goiás ao sudeste do Brasil. As duas Guerras Mundiais constituíram o segundo fator. O primeiro resultou em expressiva melhoria de infra-estrutura, enquanto o segundo aumentou o mercado de produtos agrícolas.

As áreas de matas nativas deram, então, lugar às plantações de algodão, arroz, milho, feijão e fumo, principalmente. A agricultura foi-se desenvolvendo pelo desmatamento das matas nativas enquanto o gado era criado nos campos limpos.

A construção da cidade de Brasília, o crescimento de Goiânia e o aparato administrativo das duas capitais, provocaram, na segunda metade do século $\mathrm{XX}$, uma nova dinâmica à região e ao Estado de Goiás. A nova capital do país precisava ter ligação, principalmente via terrestre, com as outras regiões, bem como uma área de produção agrícola em expansão. 
A agricultura de Goiás foi impulsionada por essa nova realidade. A produção agrícola passou a ter demanda interna e meios de transporte para os grandes centros consumidores e produtores de insumos modernos (fertilizantes, por exemplo). Nesta época, o empecilho à agricultura consistia em desenvolver tecnologias que permitissem o plantio nas condições do cerrado.

Segundo o IBGE (1995), a partir da década de 70, à medida que a exploração intensiva do cerrado tornou-se viável, houve um estímulo oficial para implantação e desenvolvimento de uma atividade agrícola moderna em Goiás, apoiada pelos crescentes investimentos em tecnologia e financiamento do custeio das safras. $O$ Estado de Goiás não dispunha de oferta de mão-de-obra agrícola redundante. Assim, segundo Nicholls (1973), não haveria a resistência social à modernização da agricultura.

Para Silva et al. (1999), foi a partir de meados dos anos 60 que o governo passou a atuar decisivamente na agricultura brasileira. Nesta época, já tinha sido implantado o modelo desenvolvimentista baseado na substituição de importação. Sentiase a necessidade de transferência de renda e fatores da agricultura para os setores industrial e de serviços. Com a maior oferta dos produtos agrícolas, a classe trabalhadora urbana poderia destinar menor parte de sua remuneração à compra de alimentos.

A forma encontrada, a princípio, para financiar a agricultura goiana e nacional foi o subsídio à atividade. $\mathrm{O}$ crédito rural foi uma das armas usadas. Porém, com fiscalização deficiente e aplicabilidade questionável, o agricultor tornou-se propenso a obter tal financiamento e investi-lo em outra atividade (Rezende, 1985). Ao mesmo tempo, somente os agricultores melhor informados quanto ao sistema vigente e com propriedades maiores, obtinham o crédito barato. Isso pode ter contribuído para a concentração da posse da terra.

Em período recente, o desenvolvimento agrícola de Goiás apresenta-se dividido em 2 fases. Ver Tabela 1. A primeira vai de 1970 a 1985 e é marcada pelo uso extensivo dos fatores de produção. A segunda etapa inicia-se em 1985 e é caracterizada principalmente pelos ganhos de produtividade dos fatores. 
Tabela 1. Situação das principais variáveis agrícolas do Estado de Goiás, 1970-1995

\begin{tabular}{|c|c|c|c|c|c|}
\hline Itens & 1970 & 1975 & 1980 & 1985 & $1995-1996$ \\
\hline Área total (ha) & 24.332 .673 & 27.690 .009 & 29.185 .281 & 29.864 .106 & 27.472 .648 \\
\hline lavouras $^{2}$ (ha) & 1.459 .760 & 2.227 .060 & 2.675 .190 & 3.324 .946 & 2.432 .494 \\
\hline Área com Pastagens ${ }^{3}$ (ha) & 17.344 .278 & 20.209 .611 & 20.099 .832 & 20.894 .584 & 19.404 .696 \\
\hline $\mathrm{N}^{\circ}$ estabelecimentos & 107.548 & 111.903 & 110.652 & 131.365 & 111.791 \\
\hline Pessoal ocupado & 394.949 & 498.230 & 543.937 & 616.336 & 471.657 \\
\hline $\mathrm{N}^{\circ}$ tratores & 5.635 & 13.084 & 24.572 & 33.548 & 43.313 \\
\hline Efetiv & 6.460 .212 & 10.581 .910 & 13.115 .072 & 14.476 .565 & 16.488 .390 \\
\hline Área & 226,25 & 247,45 & 263,76 & 227,34 & 245,75 \\
\hline Área & 6,00 & 8,04 & 9,17 & 11,13 & 8,85 \\
\hline Área & 3,70 & 4,47 & 4,92 & 5,39 & 5,16 \\
\hline Área c & 259,05 & 170,21 & 108,87 & 99,11 & 56,16 \\
\hline Área de $p$ & 71,28 & 72,99 & 68,87 & 69,97 & 70,63 \\
\hline Área de pastag & 43,92 & 40,56 & 36,95 & 33,90 & 41,14 \\
\hline Área de pastagens $/ n^{\circ}$ tratores & $3.077,96$ & $1.544,60$ & 818,00 & 622,83 & 448,01 \\
\hline Efetivo de bovinos/área total & 0,27 & 0,38 & 0,45 & 0,48 & 0,60 \\
\hline Efetivo de bovinos $/ \mathrm{n}^{\circ}$ estabelecimentos & 60,07 & 94,56 & 118,53 & 110,20 & 147,49 \\
\hline
\end{tabular}

Fonte: Dados dos Censos Agropecuários trabalhados pelo autor.

Nota: 1: O Estado do Tocantins é excluído em todo o período em análise.

2: a área de lavoura engloba a área com lavouras permanentes, temporárias e em descanso.

3: refere-se as áreas de pastagens naturais e plantadas.

Segundo Carvalho \& Arantes (1999), a área colhida no Estado de Goiás está praticamente estagnada desde 1990, mas a produção agrícola vem crescendo graças aos ganhos de produtividade. Praticamente o mesmo vem acontecendo na agropecuária brasileira (Bacha \& Rocha, 1998).

Percebe-se que a área total dos estabelecimentos, a área cultivada (área de lavouras somada à de pastagens) e o pessoal ocupado cresceram até 1980. Dois fatores podem ter contribuido para esse crescimento: elevada taxa de inflação que transformava a terra em reserva de valor e crédito rural. Daí, possivelmente, o aumento da área média dos estabelecimentos rurais.

A partir de 1985, a área total destinada à agricultura registra ligeira queda (8,8\%). Esta área passou de 29,9 milhões para 27,5 milhões de hectares. Em 1985, as porcentagens de áreas destinadas às culturas permanentes e temporárias apresentam-se acima dos níveis praticados em 1970. Por sua vez, a diminuição do número de trabalhadores ocupados é um indício de migração rural-urbana. 
O fator trabalho foi sendo substituído pelo capital. Neste sentido, constata-se uma elevação no número de tratores da ordem de $495 \%$ entre 1970 e 1985 e de apenas $29 \%$ entre 1985 e 1995. Em 1970, cada trabalhador cultivava 3,70 hectares de lavouras; em 1985 passou a cultivar 5,39 ha, e em 1995 esta relação é igual a 5,16 ha. Paralelamente, um trator cultivava 259,05 ha em 1970, 99,11 em 1985 e 56,16 hectares em 1995.

Andrade (1989) e Tarsitano (1990) encontraram resultados parecidos para a agricultura matogrossense no período de 1970 a 1985 . Houve nesse Estado aumento da área ocupada, com aumento das áreas com lavouras e pastagens. A agricultura tornou-se capital intensiva generalizando-se os gastos com máquinas e, principalmente, com insumos modernos.

É interessante notar que o número de estabelecimentos cresce até 1985 e declina a seguir. Além disso, a partir de 1985 aumentou a área média dos estabelecimentos de 227 para 246 hectares.

A bovinocultura tem crescido muito no Estado, não só em termos de produção como de produtividade. Em média, as propriedades rurais abrigavam 60,07 bovinos em 1970, 118,53 em 1980, 110,2 em 1985 e 147,5 cabeças em 1995.

De 1970 a 1995 ocorreu a concentração da posse da terra, em favor dos estabelecimentos com mais de mil hectares (Tabela 2). 
Tabela 2. Proporção do número e da área dos estabelecimentos, por grupos de área total, Goiás, 1970 - 1995.

\begin{tabular}{|c|c|c|c|c|}
\hline \multirow[t]{2}{*}{$\begin{array}{c}\text { Grupos de área total } \\
\text { (ha) }\end{array}$} & \multicolumn{2}{|c|}{$\begin{array}{c}\text { Proporção (\%) do número } \\
\text { de estabelecimentos em } \\
31.12\end{array}$} & \multicolumn{2}{|c|}{$\begin{array}{c}\text { Proporção (\%) da área dos } \\
\text { estabelecimentos em } \\
31.12 \\
\end{array}$} \\
\hline & 1970 & 1995 & 1970 & 1995 \\
\hline Menos de 10 & 13,2 & 11,2 & 0,3 & 0,3 \\
\hline 10 a menos de 100 & 50,0 & 49,3 & 9,9 & 8,9 \\
\hline 100 a menos de 1000 & 32,9 & 34,6 & 42,8 & 43,7 \\
\hline 1000 a menos de 10000 & 3,8 & 4,8 & 39,4 & 41,6 \\
\hline 10000 a mais & 0,1 & 0,1 & 7,6 & 5,5 \\
\hline Total & 100,0 & 100,0 & 100,0 & 100,0 \\
\hline
\end{tabular}

Fonte: Censo Agropecuário do IBGE (1995/96).

Observa-se o nítido crescimento das grandes propriedades. Segundo o IBGE (1995), em 1970 os estabelecimentos com menos de 100 ha representavam 63,2\% do total e detinham 10,2\% da área. Em 1995, representam $60,5 \%$ dos estabelecimentos e $9,2 \%$ de área. Ao mesmo tempo, os estabelecimentos acima de 1000 hectares que representavam $3,9 \%$ do total e controlavam $47 \%$ da área, passam para $4,9 \%$ e $47,1 \%$ respectivamente.

É sabido que a modernização da agricultura traz o aumento dos rendimentos auferidos na atividade. Para Hoffmann \& Kassouf (1989) ao mesmo tempo que aumenta a desigualdade de distribuição da renda diminui a pobreza rural absoluta. Hoffmann (1994) estudando somente a agricultura goiana, chegou a conclusões semelhantes. Houve concentração da distribuição da renda e diminuição da pobreza absoluta com a modernização da agricultura. Para o ano de 1990, este autor calculou a contribuição dos fatores sexo, idade, escolaridade e posição na ocupação (empregado, trabalhador volante, conta-própria e empregador) sobre o rendimento das pessoas ocupadas na agricultura goiana. O fator mais importante foi a posição que a pessoa ocupava dentro da 
agropecuária (33,1\% do rendimento), seguido da escolaridade $(14,6 \%)$, idade $(8,0 \%) \mathrm{e}$ sexo $(0,4 \%)$. Os empregadores auferem maiores rendas chegando a ser 4,3 vezes maior que a renda dos empregados. As mulheres, seja qual for a ocupação, recebem renda menor que a renda dos homens. As pessoas mais idosas tem rendimentos superiores aos mais novos e quanto mais escolarizados maiores são os rendimentos. Aqueles com 12 anos ou mais de estudo recebem 5,6 vezes mais do que aqueles com menos de 1 ano.

A Tabela 3 mostra o rendimento por hectare, em quilos, das principais lavouras do Estado. De fato, as seis culturas selecionadas registram ganhos de produtividade da terra, merecendo especial destaque feijão (186\%), milho (90\%) e soja $(17 \%)$.

Tabela 3. Rendimento das principais lavouras, segundo os Censos Agropecuários, Goiás, $1985-1995$.

\begin{tabular}{lrc}
\hline \multirow{2}{*}{ Lavouras } & \multicolumn{2}{c}{ Rendimento (kg/há) } \\
\cline { 2 - 3 } & 1985 & 1995 \\
\hline Algodão & 1.840 & 2.113 \\
Arroz em casca & 1.113 & 1.321 \\
Feijão em grão & 382 & 1.096 \\
Milho & 2.033 & 3.869 \\
Soja em grão & 1.931 & 2.270 \\
Café & 1.123 & 1.302 \\
\hline
\end{tabular}

Fonte: Censo Agropecuário do IBGE (1995).

\subsection{Alocação e produtividade de fatores}

A análise de alocação de recursos ou fatores é basicamente uma abordagem microeconômica freqüentemente utilizando funções de produção. Para Garófalo \& Carvalho (1985, p. 176), "a função de produção identifica a forma de solucionar os problemas técnicos da produção, por meio da apresentação das combinações de fatores que podem ser utilizadas para o desenvolvimento do processo produtivo." 
Segundo Girão (1965), foi Knut Wicksell o primeiro a descrever as relações de produção na forma matemática. Este autor considerou a produção agrícola como função da terra, trabalho e capital, tendo retornos constantes à escala.

De acordo com Silva (1996) a tentativa mais importante de determinação da forma matemática para representar as funções de produção veio de C. W. Cobb e P. H. Douglas, em 1920. Esta função se espalhou pelo meio acadêmico graças à facilidade de ajustamento e interpretação das estimativas obtidas.

Até então eram usados, como fatores nas funções estimadas, terra, capital e trabalho. Griliches (1975) acrescentou à função de produção, além dos insumos convencionais, o efeito da escolaridade e do investimento em pesquisa sobre a produção agrícola norte-americana, concluindo serem significativas essas variáveis.

Para a economia brasileira, Tinôco (1981) dizia que os produtores com maiores produções agregadas (agrícola e pecuária) apresentam níveis de escolaridade mais elevados, utilizam tecnologias mais modernas. Já Issler et al. (1996) constatou que o produto potencial no Brasil tem uma relação de longo prazo com a qualidade da força de trabalho do país (nível de escolaridade) e com os investimentos externos diretos.

Campelo \& Khan (1993) estimaram uma função de produção Cobb-Douglas modificada por Ulveling e Fletcher para o Estado do Acre com dados do IBGE para os anos de 1970 a 1985. Regrediu o valor da produção agropecuária para o i-ésimo estrato de área total com o capital empregado por estrato de área, quantidade de fator trabalho ocupado por estrato de área e a quantidade de terra por estrato de área. As elasticidades parciais encontradas foram 0,445 para a variável capital, 0,735 para o trabalho e $-0,076$ para a terra. O setor apresentou retornos crescentes a escola com o valor da soma dos coeficientes em 1,103 . Isso sugere que a fronteira agrícola poderia ser aumentada no Acre.

Patrick \& Kehrberg (1975) estudando o custo e o retorno da educação em 5 municípios brasileiros, estimaram uma função de produção em relação aos serviços dos 
fatores e à educação. Ademais, foi estimado o efeito indireto da educação sobre os serviços dos fatores. Esses autores incluíram a assistência técnica como variável independente na função estimada. A conclusão a que chegaram é que a educação tem efeito mais significativo sobre a produção agrícola nas regiões mais modernas. Nas demais localidades, a assistência técnica tem maior efeito. Quanto ao investimento em extensão rural, os autores sugerem que o mesmo seja feito a curto prazo em regiões tecnicamente mais atrasadas. Porém, a partir de um certo nivel tecnológico, deve-se investir na melhoria do capital humano.

Kassouf (1997) mediu os retornos a educação e treinamento para os homens e mulheres que trabalham tanto no setor urbano quanto rural. Pelo método de máxima verossimilhança concluiu que o aumento do número de anos de experiência e a educação têm efeito positivo na participação das pessoas no mercado de trabalho. Os retornos, tanto à educação como à experiência foram maiores no setor urbano que no rural, sendo o retorno à escolaridade maior que ao treinamento. As mulheres obtêm maiores retornos quanto à escolaridade tanto no campo como na cidade. Além disso, tiveram maiores retornos ao treinamento do que os homens no setor urbano, sendo o contrário para $\mathrm{o}$ rural.

Khan \& Silva (1997) obtiveram uma amostra dos agricultores do município cearense de Limoeiro do Norte e, pelo método de Cochran, analisaram 16 produtores assistidos e 16 não assistidos na área irrigada da referida localidade e 28 produtores assistidos e 23 não assistidos na área não irrigada. Utilizando uma função Cobb-Douglas modificada por Ulveling-Fletcher, concluem que a assistência técnica aumenta a eficiência técnica, mas não influencia as elasticidades parciais de produção.

Recentemente, Andrade (1999) analisou a contribuição do capital humano sobre o crescimento econômico brasileiro, de 1970 a 1995, através de uma função de produção Cobb-Douglas, onde o nível de educação participa como insumo. Os Estados da Federação foram enquadrados como observações para as seguintes variáveis: produto interno bruto estadual (variável dependente), produto interno bruto per capita, consumo 
de energia elétrica como proxy do estoque de capital físico, força de trabalho (representada pela População Economicamente Ativa), capital humano medido como escolaridade média por estado e o nível tecnológico representado pela variável tendência; as cinco últimas como variáveis independentes. $O$ principal resultado encontrado foi que o aumento de 1 ano de escolaridade média provocaria aumento significativo do PIB estadual.

Vicente (1989) utilizou dados dos Censos Agropecuários referentes aos anos de 1970, 1975 e 1980 para medir a contribuição da educação, assistência técnica e pesquisa agrícola para a evolução da produtividade na agricultura brasileira. Conclui que os investimentos feitos nesse período tiveram influência significativa sobre a produção agrícola, porém foram mais rentáveis aqueles aplicados na pesquisa agrícola, depois viriam aqueles em assistência técnica e, por último, na escolaridade da população rural.

Youmans \& Schuh (1975) testaram a hipótese de subemprego da mão-deobra em cinco regiões agrícolas de Minas Gerais. Em caso afirmativo, o produto marginal do trabalho seria nulo e possivelmente intenso o êxodo rural. Com o uso da função de produção Cobb-Douglas, constataram ser significativo o coeficiente de regressão da mão-de-obra e o seu valor do produto marginal maior do que o salário em três das cinco regiões estudadas.

Hayami \& Ruttan (1985) estudaram a produtividade dos fatores agrícolas e os motivos que levam os centros de pesquisas a criar novas tecnologias. Notaram que a escassez relativa de fatores, sinalizada pelos seus preços relativos, levariam à escolha do tipo de inovação. Nas regiões onde o fator terra é escasso, a nova tecnologia procuraria substitui-lo, por exemplo, pelo uso de fertilizantes. Exemplo típico desse ajustamento é o Japão. Já os Estados Unidos, com vasta extensão geográfica e escassez de mão-de-obra aparecem na literatura como país poupador de mão-de-obra e, consequentemente, priorizando as inovações mecânicas. 
Este modelo tenta explicar como o processo de desenvolvimento agrícola incorpora os mecanismos pelos quais as mudanças nos mercados de produtos e dotação de fatores interagem para influenciar a taxa e a direção de mudança tecnológica.

Engler (1978) analisando a produtividade agrícola das regiões do Estado de São Paulo, concluiu que as variáveis representativas do capital humano e insumos modernos têm grande poder de explicação das diferenças de produção e produtividade entre regiões. Para acelerar o desenvolvimento agrícola do Estado de São Paulo pode-se manter ou reduzir a área cultivada desde que se aumentem os investimentos em capital humano, na forma de pesquisa e difusão de tecnologias.

Silva (1996) estudou a contribuição dos fatores de produção na agropecuária brasileira no periodo de 1975 a 1985 . Entre os fatores incluídos no modelo CobbDouglas, ${ }^{6}$ a mão-de-obra agregada ou suas formas decompostas (mão-de-obra familiar e assalariada) constituíram as variáveis mais importantes na formação do valor da produção. A produtividade marginal do capital foi baixa.

Bonelli \& Fonseca (1998) analisaram a produtividade na economia brasileira. Analisando dados de 1970 a 1997 , e utilizando uma função de produção Cobb-Douglas, concluiram que a produtividade do trabalho é a principal responsável pelo crescimento da produtividade total dos fatores.

Nardin \& Araújo (1994) estimaram uma função de produção Cobb-Douglas, tendo como referência amostra de 287 propriedades espalhadas pelos seguintes municípios, a saber: Ariquemes - RO; Batatais - SP; Canidé - CE; Petrolina - PE; Cruz das Almas - BA; Guaíra - SP; Rondonópolis - MT; Rio Verde - GO; São Gabriel D' Oeste - MS; Ponte Nova - MG; Lajeado - RS e Carazinho - RS. Os autores estimaram o efeito da área explorada, despesas com defensivos, capital na forma de estoque de máquinas, implementos e benfeitorias; despesas com mão-de-obra e escolaridade; a variável dependente sendo o valor da produção total. Os coeficientes das variáveis área 
explorada, mão-de-obra e despesas com defensivos foram significativos ao nivel de $1 \%$. A escolaridade dos agricultores não se revelou significativa.

Conceição (1998) estimou a eficiência técnica de uma amostra de produtores da agricultura comercial do Brasil. Na amostra estudada estão produtores rurais do município de Rio Verde - GO. A pesquisa mostra que os agricultores brasileiros estão operando com retornos decrescentes à escala. Em média, a eficiência técnica dos produtores foi de $73,08 \%$ indicando que ainda podem ser perseguidos aumentos de produção e produtividade, através de políticas de difusão do conhecimento tecnológico.

Barros (1999) analisou o processo de acumulação de capital, a evolução da produtividade total dos fatores e o crescimento da agricultura brasileira entre 1970 a 1995. Os resultados indicaram que houve, nesse periodo, um forte processo de acumulação de capital. $O$ estoque de tratores aumentou 4 vezes em valor, 5 vezes em número e 6 vezes em potência. A partir de 1990 o valor da frota começa a declinar indicando o envelhecimento do estoque de máquinas agrícolas. $O$ produto agrícola cresceu 3,26\% entre 1975 e 1995 . A produtividade da terra elevou-se em $2,47 \%$ ao ano e a do trabalho em 3,26\%. Para esse autor, uma das formas de cálculo da produtividade total dos fatores é a função de produção. A variável dependente pode assumir duas versões. Na primeira, considera-se o valor da produção agrícola das lavouras; na segunda, torna-se o valor total da produção agropecuária. As variáveis explicativas especificadas foram: estoque de tratores, medido em unidade e potência; mão-de-obra, em número de equivalentes-homem; área cultivada em hectares; fertilizantes, em toneladas de nutrientes; e rebanho, em valor.

\footnotetext{
${ }^{6}$ Este autor também estimou a função de produção Ulveling-Fletcher cujos resultados foram bons, mas não diferiram dos resultados da Cobb-Douglas.
} 


\section{MATERIAL E MÉTODO}

\section{1 Área de estudo}

Esta pesquisa tem como área de estudo o Estado de Goiás. Os dados serão coletados junto aos Censos Agropecuários de 1970 a 1995-1996 e os Censos Demográficos de 1970, 1980 e 1991, ambos divulgados pelo Instituto Brasileiro de Geografia e Estatística (IBGE).

Para a análise qualitativa, houve uma mudança na base de dados. Nesse caso, a base das informações referem-se às microrregiões e mesorregiões. Em alguns casos, e quando se tornar relevante, serão apresentadas informações sobre os municípios.

Isso ocorre porque houve emancipações no decorrer do período de análise (1970 a 1995) e por causa disso as informações estão incompletas. Outro fato que justifica o agrupamento dos municípios é que eles se emanciparam, na sua maioria, entre 1988 e 1992, ficando sem comparação com os períodos anteriores.

Assim sendo, na análise quantitativa dessa pesquisa, a base de dados foi reduzida de 232 para 170 municípios. No Apêndice 1 estão os municípios que se emanciparam, suas microrregiões e suas mesorregiões.

Outro problema encontrado foi o agrupamento dos municípios em microrregiões e mesorregiões. Com o objetivo de fazer comparações no tempo, os municípios foram reagrupados em microrregiões e estas em mesorregiões de acordo com a metodologia usada nos dois últimos Censos Agropecuários. 


\subsection{Análise qualitativa}

Pretende-se medir o desempenho de variáveis econômicas e sociais utilizando análise tabular com dados disponíveis sobre o Estado. Com esse intuito, comparar-se-á a evolução histórica das seguintes variáveis:

- produção agrícola;

- crescimento da área agrícola;

- utilização de áreas com lavouras permanentes e temporárias;

- principais culturas temporárias no Estado de Goiás;

- utilização de terras com pastagens naturais e plantadas;

- rebanho bovino no Estado de Goiás;

- utilização de trabalho na agricultura;

- produtividade da terra;

- nível de investimento na agricultura;

- evolução da área cultivada por trabalhador e mecanização agrícola;

- educação e crescimento populacional;

- evolução da população brasileira e goiana; e,

- evolução da população e alfabetização rural e urbana em Goiás. 


\subsection{Análise quantitativa e modelo econométrico}

Nesta parte do trabalho, pretende-se analisar as relações de produção e produtividade no Estado de Goiás. Para Silva $(1996$, p.2) “ a análise do desempenho do setor agrícola e da combinação de fatores produtivos, com o objetivo de oferecer subsídio para a realocação e para políticas governamentais que visem ao aumento da produtividade do setor, pode ser realizada através da análise de uma função de produção agregada". Deste modo, neste trabalho será escolhida a função do tipo Cobb-Douglas. Segundo Ferguson (1991), a função de produção "é uma equação matemática (ou gráfico ou tabela) que mostra o montante máximo de produção que pode ser produzido a partir de qualquer conjunto especificado de insumos dada a tecnologia existente.

As funções de produção podem ter um caráter de curto prazo quando a tecnologia é mantida constante e nas funções de longo prazo, esta é supostamente variável. Este é o conceito de metafunção de produção. Para cada ponto tem-se uma isoquanta que representa um nível de produção. A metafunção se justifica porque cada município pode ter uma dotação de fatores diferente e produzir produtos diferentes.

Pode-se expressar matematicamente a produção $(Y)$ como função dos vários insumos (Xi):

$$
Y=f\left(X_{1}, X_{2}, \ldots X_{k}\right)
$$

Para aplicar funções de produção, como instrumento de análise na alocação de recursos, é preciso aceitar alguns pressupostos:

- existência de perfeito conhecimento do mercado de fatores e de produtos;

- divisibilidade dos insumos e produtos em qualquer proporção a fim de proporcionar um nível ótimo de uso de insumos;

- preços de produto e de fatores pré-determinados e independentes; 
- isoquantas convexas em relação à origem dos eixos das coordenadas, permitindo infinitas combinações dos fatores de produção;

- funções de produção aditivas separáveis; e,

- insumos e o produto homogêneos.

A função de produção Cobb-Douglas, tem a seguinte forma geral:

$$
Y=A X_{1}^{\hat{a}_{1}} X_{2}^{\hat{a}_{2}} \ldots X_{k}^{\hat{a}_{k}} e_{i}
$$

Onde: $\quad Y=$ é o valor da produção por município;

$A=$ uma constante positiva;

$X_{1}$ a $X_{k}=$ variáveis independentes representando os insumos de produção;

$\beta_{1}$ a $\beta_{k}=$ coeficientes da regressão, nesse tipo de função, iguais às elasticidades parciais de produção dos fatores selecionados;

$e_{i}=$ termo de erro com média zero e variância constante por pressuposição.

Para efetivar os cálculos de estimação dessa regressão será usado o método dos mínimos quadrados ordinários (MQO). Este método necessita que a equação a ser estimada seja da forma linear. Para tanto, será linearizada a função Cobb-Douglas pela aplicação de logaritmos naturais. Assim, tem-se:

$$
\ln Y=\ln A+\hat{a}_{1} \ln X_{1}+\hat{a}_{2} \ln X_{2}+\ldots+\hat{a}_{k} \ln X_{k}+\ln e_{i}
$$

ou

$$
Y^{*}=A^{*}+\hat{a}_{1} X_{1}^{*}+\hat{a}_{2} X_{2}^{*}+\ldots+\hat{a}_{k} X_{k}^{*}+\hat{e}_{1}^{*}
$$


Onde: $\quad Y^{*}=\ln Y$;

$$
\begin{aligned}
& A^{*}=\ln A ; \\
& X_{1}^{*}=\ln X_{1} \\
& X_{2}^{*}=\ln X_{2} \\
& e^{*}=\ln e_{i} \\
& X_{k}^{*}=\ln X_{k}
\end{aligned}
$$

O produto marginal de um insumo em relação ao produto total é o acréscimo do produto total atribuído ao aumento de uma unidade do insumo variável no processo produtivo, mantendo-se constantes os demais insumos. Assim, quando o produto marginal é igual a zero, indica que o produto total está em seu máximo.

O uso da função de produção Cobb-Douglas traz uma série de vantagens: i) o fato da função ser linearizável e, portanto, ser estimada pelo método dos mínimos quadrados ordinários; ii) as elasticidades de produção são os próprios coeficientes de regressão $\beta_{\mathrm{i}}$, com $\mathrm{i}=1,2, \ldots \mathrm{k}$. e independentes da quantidade de produto e de fatores; II.) facilidade na determinação de retornos à escala $\left(\Sigma \beta_{i}\right.$ 's). E reduzido numero de parâmetros, o que implica maior número de graus de liberdade e maior significância dos testes estatísticos.

Como inconvenientes, a função de produção Cobb-Douglas pressupõe que todos os fatores são indispensáveis à produção, não podendo aparecer valor zero em uma variável independente. Neste caso, além da variável dependente ser igual a zero, a linearização pelo método dos logaritmos seria impossivel. A função Cobb-Douglas não permite que se analisem os diferentes estágios de produção. 


\subsection{Variáveis da Função de Produção}

O valor bruto da produção agropecuária dos municípios de Goiás é a variável dependente. Medida em reais de 1995.

\section{- Variáveis independentes}

$\mathrm{X}_{1}=$ mão-de-obra em equivalentes-homem (eh), isto é, o total de pessoas empregadas na agricultura, por município. A transformação desta variável em equivalente-homem será feita da seguinte forma: cada homem empregado representa um equivalente-homem; cada mulher tem peso 0,6 e os menores de ambos os sexos com idade inferior a 14 anos terão peso de 0,4. Estes números são baseados em Silva (1996).

$\mathrm{X}_{2}=$ capital, medido pela potência media dos tratores, em cavalo-vapor, por município;

$\mathrm{X}_{3}=$ terra no segmento agrícola, como somatório de terras cultivadas com lavouras (permanentes e temporárias), em hectares por município.

$\mathrm{X}_{4}=$ terra com pastagens, é a soma das áreas destinadas às pastagens (naturais e plantadas) em hectares por município;

$\mathrm{X}_{5}=$ insumos modernos agrícolas, medidos pelo total de despesas, em reais de 1995 por município. Tais despesas englobam fertilizantes, corretivos de solos, herbicidas e inseticidas e sementes.

$\mathrm{X}_{6}=$ insumos modernos na pecuária, representa os gastos, em reais de 1995 por município, na compra de rações, medicamentos para animais e outros alimentos.

$\mathrm{X}_{7}=$ nível médio de escolaridade rural, por município. 


\section{RESULTADOS E DISCUSSÃO}

\subsection{Evolução das principais variáveis agrícolas}

A agricultura brasileira passou por momentos diferenciados nesses últimos 25 anos. Na década de 70, foram mais fortes os incentivos governamentais para o crescimento da produção, tanto pelo incremento de área quanto pelo aumento de produtividade. Para cumprir esse objetivo, políticas agrícolas como a de crédito rural subsidiado e de preços mínimos foram largamente utilizadas.

Fatores externos (aumento das taxas de juros internacionais) e internos (déficit público) provocaram a queda dos investimentos, inclusive em pesquisa agropecuária, e a redução dos subsídios no financiamentos do setor. A agricultura ficou a deriva e teve que se organizar para eliminar sua ineficiência alocativa.

A partir da década de 90, a agricultura sofre diretamente o peso da concorrência internacional de produtos agrícolas e insumos. Para permanecer na atividade, o agricultor teve e terá que produzir mais a custos menores sem contar, necessariamente, com o apoio de incentivos fiscais e de grandes subsídios.

A agricultura em Goiás comportou-se de maneira parecida com a nacional. Durante a década de 70, teve altas taxas de crescimento com auxílio dos incentivos governamentais. Nos anos 80 , persiste o aumento da produção, mas a taxas bem menores. $\mathrm{E}$, na década de 90 , houve queda dos principais componentes agrícolas, dentre eles o valor da produção. Ver Tabelas 4 e 5 . 
Tabela 4. Comportamento da produção, área total, trabalho e tratores agrícolas, da produtividade da terra e do trabalho na agricultura, e da relação área-homem no Estado de Goiás, 1970 - 1995.

\begin{tabular}{lccccc}
\hline \multirow{2}{*}{ Itens } & \multicolumn{5}{c}{ Anos } \\
\cline { 2 - 6 } & 1970 & 1975 & 1980 & 1985 & 1995 \\
\hline Produção (R\$1.000) & 1.076 .069 & 2.715 .630 & 3.636 .518 & 3.899 .655 & 2.582 .846 \\
Área (há) & 24.332 .673 & 27.690 .009 & 29.185 .281 & 29.864 .106 & 27.472 .648 \\
Trabalho (eh) & 394.949 & 498.230 & 543.937 & 616.336 & 471.657 \\
Tratores (n ${ }^{\circ}$ ) & 5.635 & 13.084 & 24.572 & 33.548 & 43.313 \\
Prod./área (R\$/ha) & 44,22 & 98,07 & 124,60 & 130,58 & 94,02 \\
Prod./trab.(R\$/trab.) & $2.724,58$ & $5.450,55$ & $6.685,55$ & $6.327,16$ & $5.476,11$ \\
Área/trab. (ha/trab.) & 61,61 & 55,58 & 53,66 & 48,45 & 58,25 \\
\hline
\end{tabular}

Fonte: Dados dos Censos Agropecuários, trabalhados pelo autor.

Obs.: * Os valores desta variável estão em mil reais de 1995.

**Esta variável foi medida em equivalente-homem (eh).

Percebe-se um comportamento bastante homogêneo das variáveis em exame. Crescem até 1985 e decaem a partir daí. Registre-se a exceção da variável tratores, que cresceu em todo o período.

Os dados da Tabela 5 confirmam as observações feitas sobre a tabela anterior. As variáveis crescem a taxas maiores entre 1970 a 1975 e, depois, até o ano de 1985 , crescem a ritmos menores e tornam-se negativas a partir de 1985 . Novamente a variável tratores constitui exceção. 
Tabela 5. Evolução da produção, área total, trabalho e tratores agrícolas, da produtividade da terra e do trabalho na agricultura, e da relação área-homem no Estado de Goiás, 1970 - 1995.

\begin{tabular}{lcccc}
\hline \multirow{2}{*}{ Itens } & \multicolumn{4}{c}{ Anos } \\
\cline { 2 - 5 } & $1970 / 75$ & $1975 / 80$ & $1980 / 85$ & $1985 / 95$ \\
\hline Produção & 152,37 & 33,91 & 7,24 & $-33,77$ \\
Área & 13,80 & 5,40 & 2,33 & $-8,01$ \\
Trabalho & 26,15 & 9,17 & 13,31 & $-23,47$ \\
Tratores & 132,19 & 87,80 & 36,53 & 29,11 \\
Prod./área & 121,77 & 27,05 & 4,80 & $-28,00$ \\
Prod./trab. & 100,05 & 22,66 & $-5,36$ & $-13,45$ \\
Área/homem & $-9,76$ & $-3,46$ & $-9,69$ & 20,21 \\
\hline
\end{tabular}

Fonte: Dados dos Censos Agropecuários, trabalhados pelo autor.

\subsubsection{Produção agrícola e pecuária}

Quando se analisa a produção no Estado de Goiás tem-se que focalizar o Sul do Estado. Nesta região, o clima mais apropriado e as terras de boa fertilidade fazem da mesorregião Sul Goiano a mais importante quanto a produção e distribuição de excedentes para os grandes centros de consumo.

Se a análise priorizar as microrregiões, Sudoeste de Goiás e Meia Ponte destacam-se como importantes regiões de produção vegetal e animal. Desfrutam também de malha rodoviária e hidroviária para o escoamento da produção para São Paulo, Triângulo Mineiro, Belo Horizonte e Distrito Federal.

Quanto ao valor da produção de Goiás, o mesmo não chega a ser dos mais expressivos no cenário nacional, com exceção do ano de 1985. Ver Tabela 6. 
Tabela 6. Valor real da produção agrícola brasileira e goiana, 1970 - 1995.

\begin{tabular}{cccc}
\hline Anos & Brasil (R\$1.000) & Goiás (R \$1.000) & $\%$ \\
\hline 1970 & 29.430 .509 & 1.076 .069 & 3,66 \\
1975 & 61.416 .558 & 2.715 .630 & 4,42 \\
1980 & 79.104 .097 & 3.636 .518 & 4,60 \\
1985 & 29.435 .569 & 3.899 .655 & 13,25 \\
1995 & 47.796 .077 & 2.582 .846 & 5,40 \\
\hline
\end{tabular}

Fonte: Dados dos Censos Agropecuários trabalhados pelo autor.

Obs.: Valores deflacionados pelo IGP-DI, em reais de dezembro de 1995.

Em 1970, a produção agrícola brasileira foi de 29,4 bilhões $^{7}$ de reais. A participação do Estado de Goiás foi de 3,66\%, o que representa algo próximo de 1,1 bilhão de reais.

Sobre as microrregiões, em 1970 o Sudoeste de Goiás com 19,91\%, Meia Ponte $13,01 \%$ e Anápolis ${ }^{8} 10,5 \%$ foram as que mais se destacaram na produção agrícola e pecuária do Estado.

Anápolis constitui um caso a parte. Teve essa representatividade graças à proximidade dos grandes centros consumidores da época, como a própria cidade de Anápolis, Goiânia e Brasilia. À medida que Meia Ponte e o Sudoeste de Goiás vão crescendo e produzindo a custos menores, elas passam a suprir as necessidades daqueles centros e reduzem a importância da microrregião de Anápolis.

Quanto à participação dos municipios, os que mais se destacaram foram Rio Verde, Santa Helena de Goiás (do Sudoeste de Goiás) e Itumbiara (Meia Ponte) com $\mathrm{R} \$ 72,5 ; \mathrm{R} \$ 52,5$ e R \$36,4 milhões, respectivamente.

A participação de Goiás no cenário nacional aumentou para 4,42\% em 1975. Houve um crescimento de $152,37 \%$ na produção agropecuária goiana passando de 1,1 bilhão de reais para R\$2,7 bilhões. Meia Ponte $(13,09 \%)$ do total do Estado e Sudoeste

\footnotetext{
${ }^{7}$ As variáveis que expressam valores monetários foram deflacionadas pelo IGP - DI com base em dez/95.

${ }^{8}$ Este é um município do Estado de Goiás. Pela nomenclatura adotada pelo IBGE, as microrregiões, na sua maioria, têm o mesmo nome do seu principal município.
} 
de Goiás $(12,83 \%)$ são as microrregiões mais representativas. Quanto à participação dos municípios, Rio Verde, Itumbiara e Paraúna foram os de maior destaque, com R $\$ 105,9$, $\mathrm{R} \$ 87,4$ e R $\$ 83,2$ milhões, respectivamente.

O Censo Agropecuário de 1980 registra queda da taxa de crescimento da agricultura no Estado de Goiás. A taxa de crescimento foi de 33,91\% no último quinquênio da década de 70, quando a produção atingiu 3,6 bilhões de reais. Sudoeste de Goiás e Meia Ponte continuaram sendo as principais microrregiões, porém houve mudanças na posição dos municípios. Rio Verde foi o principal produtor com $\mathrm{R} \$ 163,4$ milhões, seguido de Quirinópolis, Itumbiara e Crixás que produziram, respectivamente, R \$139,7; R \$138,9 e R\$105,8 milhões.

Em 1985, a importância da agricultura goiana frente a nacional foi bastante significativa. Dos 29,4 bilhões de reais produzidos no Brasil, 3,9 bilhões vieram de Goiás, o que representou 13,25\%. Quanto ao crescimento da produção no Estado, ela cresceu 7,24\% entre 1980 a 1985; a agricultura nacional teve decréscimo de $62,79 \%$ em termos reais. Percebe-se, portanto, que o primeiro quinquênio da década de 80 foi de crise para o setor agrícola nacional e de crescimento para a agricultura em Goiás.

O Sudoeste de Goiás produziu R $\$ 654,3$ milhões, representando $16,78 \%$ do total do Estado e Meia Ponte foi a segunda microrregião, produzindo $\mathbf{R} \$ 494,2$ milhões $(12,67 \%)$. Entre os municípios, contribuíram significativamente para esse crescimento Rio Verde, Quirinópolis e Jataí, com valores de $\mathrm{R} \$ 222,5$ milhões, $\mathrm{R} \$ 115,5$ milhões e $\mathrm{R} \$ 102,8$ milhões, respectivamente.

Em 1995, a produção agropecuária goiana responde por $5,4 \%$ do total produzido no Brasil. Nas microrregiões, Sudoeste de Goiás consolida sua agricultura e representa 21,73\% da capacidade produtiva do Estado. Meia Ponte a segue com 13,69\%; entre os municípios, Rio Verde (R $\$ 128,9$ milhões), Jataí (R $\$ 95,7$ milhões) e Goiatuba (81,9 milhões) foram os de maior produção. 
Neste mesmo período, a economia goiana registra a queda de $\mathrm{R} \$ 3,9$ milhões para $\mathrm{R} \$ 2,5$ milhões no valor da produção. Isso sinalizava períodos de incerteza e pessimismo quanto ao futuro. Já em 1991 Fernando Homem de Melo alertava que a queda de preços compromete a rentabilidade dos produtores. Para esse autor, o governo deveria ser o mediador entre preços e rendas na agricultura. Mesmo assim, a agricultura goiana contribuiu para o desenvolvimento do país, produzindo mais a preços menores.

Com efeito, chama atenção ser a queda do valor produzido (cerca de $34 \%$ ) explicada pela queda dos preços reais da economia agrícola goiana no período 19851995. A Tabela 7 registra a evolução dos preços agrícolas pelo método de Laspeyres, para as principais culturas do Estado de Goiás no período analisado.

Tabela 7. Evolução dos preços reais dos principais produtos agrícolas no Estado de Goiás, $1970-1995$.

\begin{tabular}{|c|c|c|c|c|c|}
\hline \multirow{2}{*}{ Produtos } & \multicolumn{5}{|c|}{ Ano } \\
\hline & 1970 & 1975 & 1980 & 1985 & 1995 \\
\hline Soja & 100,00 & 115,01 & 92,46 & 79,33 & 20,34 \\
\hline Arroz & 100,00 & 201,68 & 136,07 & 117,80 & 47,61 \\
\hline Algodão & 100,00 & 122,99 & 101,55 & 80,53 & 44,85 \\
\hline Milho & 100,00 & 171,49 & 185,81 & 152,89 & 68,17 \\
\hline Feijão & 100,00 & 150,83 & 234,50 & 107,24 & 61,68 \\
\hline Mandioca & 100,00 & 157,62 & 259,20 & 258,16 & 152,40 \\
\hline Cana-de-açúcar & 100,00 & 153,32 & 121,63 & 86,99 & 113,10 \\
\hline Café & 100,00 & 194,45 & 221,44 & 261,68 & 97,00 \\
\hline Índice geral & 100,00 & 139,26 & 169,08 & 143,08 & 75,64 \\
\hline Indice parcial ${ }^{*}$ & 100,00 & 159,75 & 162,21 & 114,32 & 49,45 \\
\hline
\end{tabular}

Fonte: Dados dos Censos Agropecuários trabalhados pelo autor.

* Média aritmética dos índices dos preços de soja, milho, arroz e feijão.

Esta tabela tem dois índices. Um deles engloba os preços reais de 8 produtos agrícolas que juntos ocuparam mais de $80 \%$ da área cultivada do Estado. $\mathrm{O}$ outro descreve o comportamento das quatro principais culturas: soja, milho, arroz e feijão. 
Percebe-se que a soja teve o menor preço real do período. Houve crescimento real de preços de $15,01 \%$ no período de 1970 a 1975 e queda a partir desse ano. Em 1995, os preços estavam 79,66\% menores que em 1970. O milho apresenta comportamento similar. Cresce até 1980 quando estava 85,81\% acima dos níveis praticados em 1970. A partir dai, há uma queda significativa dos preços, ficando, em 1995, 31,83\% abaixo do nível de 1970 .

Este quadro não difere para as culturas de algodão e café. Cana-de-açúcar e mandioca são os únicos produtos cujos preços situaram-se, em 1995, acima dos preços de 1970.

Os preços das quatro lavouras principais no Estado cresceram $62,21 \%$ na década de 70. Mas, tiveram queda vertiginosa até 1995 quando estavam $50,55 \%$ abaixo dos níveis de 1970. O índice dos 8 principais produtos teve comportamento semelhante. Cresce mais na década de $70(69,08 \%)$ e cai menos para o último período em análise $(24,36 \%)$.

Os agricultores goianos têm aumentado a quantidade produzida. Possivelmente, por estarem realizando expressivos ganhos de produtividade, com reduções dos custos médios. ${ }^{9} \mathrm{Na}$ tabela 8 , registra-se o crescimento das quantidades produzidas pelo método de Laspeyres.

\footnotetext{
${ }^{9}$ Homem de Melo (1992) argumenta que os preços reais dos insumos agrícolas estiveram em queda durante a década de 80 . Isso constitui indício de queda dos custos médios. Porém, conforme argumento Diesel et al. (1997) a abertura econômica, a partir do início da década de 90, beneficiou o consumo de fertilizantes, mas, já se nota uma recuperação de preços desde 1994.
} 
Tabela 8. Evolução do índice de quantidade das principais lavouras no Estado de Goiás, $1970-1995$.

\begin{tabular}{lccccc}
\hline \multirow{2}{*}{ Produtos } & \multicolumn{5}{c}{ Ano } \\
\cline { 2 - 6 } & 1970 & 1975 & 1980 & 1985 & 1995 \\
\hline Soja & 100,00 & 692,82 & $3.306,43$ & $1.924,36$ & $12.769,91$ \\
Arroz & 100,00 & 116,82 & 135,27 & 97,72 & 26,67 \\
Algodão & 100,00 & 69,82 & 74,64 & 131,26 & 208,21 \\
Milho & 100,00 & 200,66 & 235,40 & 290,50 & 616,80 \\
Feijão & 100,00 & 90,51 & 78,28 & 124,75 & 110,78 \\
Mandioca & 100,00 & 49,34 & 44,70 & 79,99 & 211,79 \\
Cana & 100,00 & 165,80 & 390,28 & $2.513,69$ & $2.886,24$ \\
Café & 100,00 & 129,85 & 614,45 & 483,93 & 108,79 \\
Índice geral $^{*}$ & 100,00 & 149,98 & 542,16 & 627,36 & $1.882,14$ \\
Índice parcial $^{*}$ & 100,00 & 168,73 & 609,93 & 705,77 & $2.117,40$ \\
\hline Fyyyyy
\end{tabular}

Fonte: Dados dos Censos Agropecuários trabalhados pelo autor.

* Média aritmética das quatro principais culturas: soja, milho, arroz e feijão.

A análise de valor da produção de cada uma das principais culturas do Estado revela, de acordo com a Tabela 9, que o aumento na quantidade foi suficiente para manter crescente o valor recebido pela venda da produção na maioria das culturas. Revela, também, que para o ano de 1995, todas as culturas, exceção feita à cana-deaçúcar, tiveram queda de valor em relação a 1985. 
Tabela 9. Valor real da produção (IGP-DI, FGV), em mil reais de 1995, das principais culturas do Estado de Goiás, 1970 - 1995.

\begin{tabular}{lccccc}
\hline \multirow{2}{*}{ Culturas } & \multicolumn{5}{c}{ Ano } \\
\cline { 2 - 6 } & 1970 & 1975 & 1980 & 1985 & 1995 \\
\hline Soja & $4.341,27$ & $46.534,44$ & $162.991,09$ & $429.705,58$ & $372.742,00$ \\
Arroz & $285.341,84$ & $677.699,31$ & $529.177,30$ & $335.001,86$ & $35.260,00$ \\
Algodão & $63.626,84$ & $58.529,31$ & $60.205,40$ & $80.930,09$ & $66.845,00$ \\
Milho & $83.937,59$ & $296.923,45$ & $360.602,19$ & $377.055,57$ & $317.440,00$ \\
Feijão & $72.105,47$ & $99.925,93$ & $133.002,23$ & $98.312,91$ & $45.347,00$ \\
Mandioca & $7.486,13$ & $5.583,30$ & $6.481,38$ & $15.338,27$ & $12.481,00$ \\
Cana & $6.593,83$ & $10.077,41$ & $26.772,94$ & $133.742,29$ & $180.351,00$ \\
Café & $2.555,49$ & $7.244,25$ & $32.929,05$ & $36.131,45$ & $3.796,00$ \\
Total & $525.988,47$ & $1.192 .440,01$ & $1.312 .161,58$ & $1.506 .218,03$ & $1.034 .262,00$ \\
\hline
\end{tabular}

Fonte: Dados dos Censos Agropecuários trabalhados pelo autor.

As lavouras que se destinam ao abastecimento do mercado externo ou são ligadas a agroindústrias tiveram queda menor no valor da produção ou até mesmo algum crescimento (soja, milho e cana-de-açúcar). As destinadas ao mercado interno tiveram perda mais significativa de valor (arroz e feijão).

\subsubsection{Crescimento da área agrícola}

Com os incentivos governamentais, foi a partir da década de 70 que houve a expansão da fronteira agrícola no Brasil Central.

Homem de Melo (1985) dizia que o crescimento extensivo da agricultura brasileira já se encontrava prestes a se esgotar. Haveria a necessidade de incentivos e melhoria tecnológica para que a oferta agrícola se mantivesse crescendo.

Esses incentivos, principalmente, na forma de subsídios, foram objetivados em expansão da área de culturas temporárias. Quanto à área de pastagens, continuou predominando no Estado, pois o mesmo conta com expressivo rebanho bovino em todo o seu território. 
Vale mencionar que, em 1970, o Estado dispunha de 24,3 milhões de hectares como área total potencialmente a serviço da agricultura (área agricultável mais área improdutiva), conforme ilustra a Tabela 8. Essa área cresce até 1985 quando atinge 29,8 milhões. Em 1995, há o registro de queda de $8,01 \%$ o que disponibilizou 27,4 milhões de hectares.

A Tabela 10 indica os valores das principais variáveis em estudo nesse item.

Tabela 10. Variáveis referentes a utilização potencial das terras pela agricultura do Estado de Goiás, 1970 - 1995.

\begin{tabular}{lccccc}
\hline Itens (há) & 1970 & 1975 & 1980 & 1985 & 1995 \\
\hline Área total & 24.332 .673 & 27.690 .009 & 29.185 .281 & 29.864 .106 & 27.472 .648 \\
Área agricultável & 23.260 .198 & 26.529 .570 & 27.613 .355 & 28.359 .150 & 26.230 .045 \\
Lav. Perm. & 61.433 & 47.496 & 58.963 & 62.974 & 55.787 \\
Lav. Temp. & 1.398 .327 & 2.179 .564 & 2.616 .227 & 2.865 .225 & 2.119 .066 \\
Past. Natur. & 13.617 .785 & 14.151 .044 & 11.617 .404 & 9.569 .989 & 5.137 .285 \\
Past. Plant. & 3.726 .493 & 6.058 .567 & 8.482 .428 & 11.324 .595 & 14.267 .411 \\
Matas natur. & 2.402 .133 & 2.537 .636 & 3.146 .292 & 2.828 .529 & 3.774 .654 \\
Matas plant. & 18.244 & 20.268 & 74.966 & 83.630 & 72.652 \\
Lav. Descanso & 2.035 .783 & 81.102 & 271.567 & 396.747 & 2.119 .066 \\
Produt. Não util. & - & 1.453 .893 & 1.345 .508 & 1.227 .461 & 545.549 \\
Improdutivas & 1.072 .475 & 1.160 .439 & 1.571 .926 & 1.504 .956 & 1.242 .603 \\
\hline Pos Cens Agne
\end{tabular}

Fonte: Censos Agropecuários - dados da pesquisa.

\subsubsection{Utilização de áreas com lavouras permanentes e temporárias}

Conforme apontado anteriormente, são praticamente inexpressivas as áreas de lavouras permanentes. Somente alguns municípios têm vantagens naturais para o cultivo de culturas perenes. Quando a lavouras temporárias, o Estado vem aumentando a área sob cultivo, apesar de algumas oscilações anuais. Ver Tabela 11. 
Tabela 11. Porcentagem da área agricultável destinada a lavouras permanentes e temporárias no Estado de Goiás, 1970 - 1995.

\begin{tabular}{lcc}
\hline Anos & Lavouras Permanentes & Lavouras Temporárias \\
\hline 1970 & 0,26 & 6,01 \\
1975 & 0,18 & 8,22 \\
1980 & 0,21 & 9,47 \\
1985 & 0,22 & 10,10 \\
1995 & 0,21 & 8,08 \\
\hline
\end{tabular}

Fonte: Dados dos Censos Agropecuários trabalhados pelo autor.

Conforme a tabela acima, a área com lavouras permanentes não chega a $1 \%$ do total das terras agricultáveis. A área de lavouras temporárias se mantém em crescimento até o ano de 1985. Em 1995, perde dois pontos percentuais.

Quanto as lavouras permanentes, estas se concentram nas mesorregiões Sul e Centro Goiano.

\subsection{Principais culturas temporárias no Estado de Goiás}

De 1970 a 1995, o Estado de Goiás apresenta-se como grande produtor de poucos produtos. Na década de 70 houve destaque para o arroz e o milho. A partir de 1985, a soja ocupa o lugar do arroz e forma com o milho as maiores áreas em plantio ${ }^{10}$.

Em Goiás, houve incorporação de novas áreas e ganhos de produtividade. Já no Estado do Rio Grande do Norte, estudado por Moreira (1996), o crescimento da produção agricola situou-se na taxa de 1,66\% ao ano entre 1981 a 1992. Isso não ocorreu pela incorporação de novas áreas mas pelo crescimento decorrente dos efeitos composição da produção, rendimento e localização geográfica.

A explicação da perda de importância do arroz no Estado de Goiás, produto básico da alimentação do brasileiro, pode ser atribuída ao risco da atividade e à baixa elasticidade renda de sua demanda. O tipo de arroz preferido nos grandes centros é o

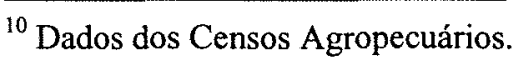


agulhinha que não é tradicional no Estado. Em Goiás, as lavouras são formadas com a arroz de sequeiro que não têm boa aceitação na mesa dos consumidores, principalmente de outros Estados.

A abertura econômica da década de 90 e a formação do Mercosul, influenciaram a rizicultura goiana. Com a abertura comercial, muitos produtores desistiram da atividade. Ao mesmo tempo, o mercado interno foi abastecido pelo produto de outros países, com vantagem comparativa maior.

Assim, a partir da década de 80 e principalmente de 90 , a produção de arroz teve queda vertiginosa. Ver Tabela 12.

Tabela 12. Produção, área colhida e produtividade do arroz no Estado de Goiás, 1970 1995.

\begin{tabular}{lrrrrr}
\hline Anos & Produção (t) & $\begin{array}{c}\text { Cresc. Prod. } \\
(\%)\end{array}$ & Área (ha) & $\begin{array}{r}\text { Produtividade } \\
(\mathrm{kg} / \mathrm{ha})\end{array}$ & $\begin{array}{c}\text { Cresc. Produtiv. } \\
(\%)\end{array}$ \\
\hline 1970 & 773.811 & - & 792.614 & 976 & - \\
1975 & 914.280 & 18,15 & 972.494 & 940 & $-3,70$ \\
1980 & 1.075 .694 & 17,65 & 1.000 .328 & 1.075 & 14,38 \\
1985 & 771.188 & $-28,31$ & 693.004 & 1.113 & 3,48 \\
1995 & 201.115 & $-73,92$ & 152.253 & 1.321 & 18,70 \\
\hline
\end{tabular}

Fonte: Dados dos Censos Agropecuários trabalhados pelo autor.

A cultura do feijão teve comportamento parecido com a de arroz quanto à área. Sua participação foi declinante no periodo em estudo. Ver Tabela 13. Em 1970, do total da área cultivada com lavouras temporárias, 14,78\% eram destinados ao cultivo de feijão. Nos anos censitários seguintes (1975, 1980, 1985 e 1995) as estatísticas correspondentes caem para 9,59\%,7,99\%,9,07\% e 3,55\%, respectivamente. 
Tabela 13. Produção, área colhida e produtividade de feijão no Estado de Goiás, 1970 1995.

\begin{tabular}{lccccc}
\hline Anos & Produção (t) & $\begin{array}{c}\text { Cresc. Prod. } \\
(\%)\end{array}$ & Área (ha) & $\begin{array}{r}\text { Produtividade } \\
(\mathrm{kg} / \mathrm{ha})\end{array}$ & $\begin{array}{c}\text { Cresc. Produtiv. } \\
(\%)\end{array}$ \\
\hline 1970 & 79.873 & - & 229.277 & 348 & - \\
1975 & 71.904 & $-9,98$ & 213.565 & 337 & $-3,35$ \\
1980 & 62.629 & $-12,90$ & 213.662 & 293 & $-12,94$ \\
1985 & 101.551 & 62,15 & 265.566 & 382 & 30,46 \\
1995 & 84.768 & $-16,53$ & 77.293 & 1.096 & 186,80 \\
\hline
\end{tabular}

Fonte: Dados dos Censos Agropecuários trabalhados pelo autor.

Milho e soja têm maior mercado consumidor em razão dos seus produtos derivados. São matérias-primas para rações do complexo agroindustrial do frango e dos suínos, principalmente. $\mathrm{O}$ crescimento dessas indústrias condiciona $\mathrm{o}$ aumento da procura pelo milho e soja.

Ao contrário do que ocorreu com o arroz e feijão, o milho vem incorporando aumentos de quantidade, área e produtividade. Ver Tabela 14.

Tabela 14. Produção, área colhida e produtividade de milho no Estado de Goiás, 1970 1995.

\begin{tabular}{lccccc}
\hline Anos & Produção $(\mathrm{t})$ & $\begin{array}{c}\text { Cresc. Prod. } \\
(\%)\end{array}$ & Área (ha) & $\begin{array}{c}\text { Produtividade } \\
(\mathrm{kg} / \mathrm{ha})\end{array}$ & $\begin{array}{c}\text { Cresc. Produtiv. } \\
(\%)\end{array}$ \\
\hline 1970 & 513.206 & - & 432.356 & 1.187 & - \\
1975 & 1.051 .724 & 104,93 & 623.853 & 1.686 & 42,03 \\
1980 & 1.233 .272 & 17,26 & 670.534 & 1.839 & 9,09 \\
1985 & 1.507 .829 & 22,26 & 741.754 & 2.033 & 10,52 \\
1995 & 2.971 .570 & 97,07 & 768.086 & 3.869 & 90,32 \\
\hline
\end{tabular}

Fonte: Dados dos Censos Agropecuários trabalhados pelo autor.

A cultura do milho ocupava $27,87 \%$ das áreas de lavouras no Estado de Goiás em 1970. Nos anos seguintes, as posições relativas observadas para a área cultivada com o milho foram respectivamente, $28,01 \%, 25,06 \%, 25,33 \%$ e $35,32 \%$. Vale 
destacar, também, que a tendência de aumento da área em valores absolutos, é crescente nos últimos 25 anos.

Atualmente, a soja é a cultura de maior destaque dentre as quatro analisadas. Sua produção teve crescimento dos mais expressivos no Estado de Goiás, passando de 9.278 toneladas em 1970 para 1.960.112 toneladas em 1995. Ver Tabela 15.

Tabela 15. Produção, área colhida e produtividade de soja no Estado de Goiás, 1970 1995.

\begin{tabular}{|c|c|c|c|c|c|}
\hline Anos & Produção (t) & $\begin{array}{c}\text { Cresc. Prod. } \\
(\%)\end{array}$ & Área (ha) & $\begin{array}{l}\text { Produtividade } \\
(\mathrm{kg} / \mathrm{ha})\end{array}$ & $\begin{array}{c}\text { Cresc. Produtiv. } \\
(\%) \\
\end{array}$ \\
\hline 1970 & 9.278 & - & 10.588 & 876 & - \\
\hline 1975 & 82.170 & 785,64 & 61.894 & 1.328 & 51,50 \\
\hline 1980 & 368.409 & 348,35 & 213.400 & 1.726 & 30,04 \\
\hline 1985 & 1.157 .646 & 214,23 & 599.488 & 1.931 & 11,86 \\
\hline 1995 & 1.960 .112 & 69,32 & 863.422 & 2.270 & 17,56 \\
\hline
\end{tabular}

Fonte: Dados dos Censos Agropecuários trabalhados pelo autor.

Na tabela acima, observa-se que a produção e a produtividade revelam tendência decrescente. Isso porque a soja teve seu crescimento explicado mais pelo crescimento de área e não da produtividade da terra. Os agricultores estão incorporando áreas ociosas das outras culturas com o cultivo da soja. Este cresce utilizando os equipamentos das culturas substituídas.

Barbosa (1987), Cunha et al. (1994) e Sousa (1990) confirmam que a soja foi implantada na fronteira agrícola devido ao ganho tecnológico que adquiriu e aos incentivos recebidos. É uma cultura que se adapta à mecanização e à demanda do complexo agroindustrial que migrou para o Estado. 


\subsubsection{Utilização de terras com pastagens naturais e plantadas}

A criação de bovinos é atividade importante no Estado desde a sua formação. Para tanto, enormes áreas que poderiam ser utilizadas na agricultura são destinadas à pecuária.

$\mathrm{Na}$ década de 70, a utilização dos campos abertos com pastagens naturais para o gado era comum nas fazendas goianas. Com o tempo, o pisoteio dos animais transformou essas pastagens em áreas improdutivas ou com baixa capacidade de alimentação. Com redução progressiva da abertura de novas fronteiras agrícolas, as fazendas tiveram que substituir a pastagem antiga por outras de melhor qualidade nutricional e mais resistentes. Isso porque o pecuarista vem ao longo dessas três décadas buscando a melhoria de produtividade na atividade. Resulta, então, a queda da área com pastagens naturais em favor da área com pastagens plantadas, (Tabela 16).

Tabela 16. Participação das áreas com pastagens naturais e plantadas na área total agricultável do Estado de Goiás, 1970 - 1995.

\begin{tabular}{lcc}
\hline Anos & Pastagens naturais & Pastagens plantadas \\
\hline 1970 & 58,55 & 16,02 \\
1975 & 53,34 & 22,84 \\
1980 & 42,07 & 30,72 \\
1985 & 33,75 & 39,93 \\
1995 & 19,59 & 54,39 \\
\hline
\end{tabular}

Fonte: Dados dos Censos Agropecuários trabalhados pelo autor.

\subsection{Rebanho bovino no Estado de Goiás}

Em 1970, o Brasil possuía 78,5 milhões de bovinos e destes 6,4 milhões estavam em Goiás. No período de 1970 a 1975, o crescimento do rebanho brasileiro foi de $29,42 \%$ e em Goiás esta cifra atinge $63,80 \%$. 
No segundo quinquênio da referida década, não se nota o mesmo dinamismo de crescimento. No Brasil, o crescimento da bovinocultura foi da ordem de $20,61 \%$ contra $23,94 \%$ no Estado de Goiás. A explicação para isso talvez seja o crescimento da agricultura, impulsionada pelas vantagens do crédito agrícola subsidiado e pela demanda crescente por alimentos, decorrente do crescimento da população e da renda, como mostra a Tabela 17.

Tabela 17. Evolução do rebanho bovino nacional e goiano, $1970-1995$.

\begin{tabular}{crccc}
\hline Ano & Brasil & Crescimento (\%) & Goiás & Crescimento (\%) \\
\hline 1970 & 78.562 .250 & - & 6.460 .212 & - \\
1975 & 101.673 .753 & 29,42 & 10.581 .910 & 63,80 \\
1980 & 122.632 .425 & 20,61 & 13.115 .072 & 23,94 \\
1985 & 128.041 .757 & 4,41 & 14.476 .565 & 10,38 \\
1995 & 153.058 .275 & 19,54 & 16.488 .390 & 13,90 \\
\hline
\end{tabular}

Fonte: Dados dos Censos Agropecuários trabalhados pelo autor.

A década de 80 foi marcada pelo modesto crescimento da economia brasileira. Com o crescimento populacional acima do crescimento do PIB, a renda per capita não cresceu no período e em vários anos registrou até variação negativa ${ }^{11}$. Mesmo assim, no Estado de Goiás o crescimento do rebanho bovino ficou acima do rebanho brasileiro; em 1985 o Estado passou a abrigar 14,5 milhões de bovinos.

De 1985 a 1995 houve mudanças significativas no cenário macro do país. Os choques heterodoxos e a política de abertura ao comércio internacional podem ter contribuído para a elevação do rebanho bovino no país (19,54\%). Goiás respondeu a essas políticas de forma lenta, com a elevação de seus rebanhos abaixo do ocorrido no Brasil. Motivo provável para isso é que o rebanho goiano não estava livre da febre aftosa e de outras doenças e, portanto, o Estado não se beneficiou das oportunidades do mercado externo.

\footnotetext{
${ }^{11}$ Para maiores detalhes, ver Bacha, 1996, p. 32 e seguintes.
} 
No período 1970-1995, o Estado teve produção crescente com a tendência altista dos preços. Porém a taxas declinantes. Enquanto a produção brasileira apresenta taxas de crescimento superiores a do Estado, internamente, algumas regiões de Goiás destacaram-se pelo dinamismo na criação de bovinos.

Nesse sentido, a Tabela 18 destaca o caso das microrregiões do Sudoeste de Goiás e Meia Ponte. Os municípios maiores produtores, em 1970, foram Rio Verde, Goiás, Caiapônia, Jataí e São Miguel do Araguaia.

Tabela 18. Total de bovinos por microrregião em Goiás, 1970 - 1980.

\begin{tabular}{lrrrrrr}
\hline \multirow{2}{*}{ Microrregião } & \multicolumn{2}{c}{1970} & \multicolumn{2}{c}{1975} & \multicolumn{2}{c}{1980} \\
\cline { 2 - 7 } & Quantid. Prod. & $(\%)$ & Quantid. Prod. & $(\%)$ & Quantid. Prod. & $(\%)$ \\
\hline Anápolis & 411.422 & 6,37 & 578.331 & 5,47 & 662.973 & 5,06 \\
Anicuns & 364.936 & 5,65 & 473.804 & 4,48 & 492.016 & 3,75 \\
Ceres & 396.181 & 6,13 & 620.084 & 5,86 & 742.784 & 5,66 \\
Goiânia & 268.424 & 4,16 & 362.581 & 3,43 & 437.205 & 3,33 \\
Iporá & 327.802 & 5,07 & 479.757 & 4,53 & 470.974 & 3,59 \\
Entorno de Brasília & 389.907 & 6,04 & 723.918 & 6,84 & 778.416 & 5,94 \\
Vão do Paranã & 114.619 & 1,77 & 226.238 & 2,14 & 322.993 & 2,46 \\
Aragarças & 172.186 & 2,67 & 271.297 & 2,56 & 379.809 & 2,90 \\
Rio Vermelho & 367.144 & 5,68 & 759.963 & 7,18 & 939.610 & 7,16 \\
São Miguel do Araguaia & 304.323 & 4,71 & 781.323 & 7,38 & 970.120 & 7,40 \\
Chapada dos Veadeiros & 83.659 & 1,29 & 134.065 & 1,27 & 177.694 & 1,35 \\
Porangatu & 323.267 & 5,00 & 586.148 & 5,54 & 742.021 & 5,66 \\
Catalão & 431.969 & 6,69 & 556.262 & 5,26 & 529.292 & 4,04 \\
Meia Ponte & 714.170 & 11,05 & 1.178 .558 & 11,14 & 1.409 .608 & 10,75 \\
Pires do Rio & 239.975 & 3,71 & 338.856 & 3,20 & 352.447 & 2,69 \\
Quirinópolis & 455.314 & 7,05 & 772.374 & 7,30 & 1.231 .749 & 9,39 \\
Sudoeste de Goiás & 780.437 & 12,08 & 1.169 .669 & 11,05 & 1.709 .178 & 13,03 \\
Vale do Rio dos Bois & 314.477 & 4,87 & 568.682 & 5,37 & 766.183 & 5,84 \\
Totais & 6.460 .212 & 100,00 & 10.581 .910 & 100,00 & 13.115 .072 & 100,00 \\
\hline
\end{tabular}

Fonte: Dados dos Censos Agropecuários trabalhados pelo autor.

Para 1975, o Censo Agropecuário registra um crescimento do rebanho bovino no Estado da ordem de 63,80\%, atingindo 10,6 milhões de cabeças. 
As microrregiões de Meia Ponte e do Sudoeste de Goiás foram as mais expressivas em participação, com $11,14 \%$ e $11,05 \%$, respectivamente.

De 1975 a 1980, o rebanho goiano cresceu 23,94\% e atingiu 14.476 .565 cabeças. Houve uma queda no dinamismo da bovinocultura. As duas principais microrregiões produtoras foram o Sudoeste de Goiás (13,03\%) e Meia Ponte $(10,75 \%)$. Quanto aos municípios, Crixás com 595.951 cabeças se destaca. É seguido por Rio Verde (490.400), Quirinópolis (406.882), Goiás (347.419), Jataí (319.970) e Caiapônia $(303.569)$.

No período 1985-1995, o Sudoeste de Goiás se consolida como maior produtor de bovinos do Estado ao abrigar 2,3 milhões de cabeças (13,97\% do total). Ver Tabela 19.

Tabela 19. Total de bovinos por microrregião em Goiás, 1985 - 1995.

\begin{tabular}{lrrrr}
\hline \multirow{2}{*}{ Microrregião } & \multicolumn{2}{c}{1985} & \multicolumn{1}{c}{1995} \\
\cline { 2 - 5 } & Quantid. Prod. & \multicolumn{1}{c}{$\%$} & Quantid. Prod. & \multicolumn{1}{c}{$\%$} \\
\hline Anápolis & 590.231 & 4,08 & 707.138 & 4,29 \\
Anicuns & 544.020 & 3,76 & 575.676 & 3,49 \\
Ceres & 812.376 & 5,61 & 908.028 & 5,51 \\
Goiânia & 436.447 & 3,01 & 489.422 & 2,97 \\
Iporá & 474.171 & 3,28 & 537.335 & 3,26 \\
Entorno de Brasília & 931.708 & 6,44 & 1.045 .924 & 6,34 \\
Vão do Paranã & 385.408 & 2,66 & 434.204 & 2,63 \\
Aragarças & 461.956 & 3,19 & 651.182 & 3,95 \\
Rio Vermelho & 995.741 & 6,88 & 1.304 .952 & 7,91 \\
São Miguel do Araguaia & 891.012 & 6,15 & 1.296 .806 & 7,86 \\
Chapada dos Veadeiros & 213.561 & 1,48 & 276.560 & 1,68 \\
Porangatu & 909.325 & 6,28 & 1.174 .435 & 7,12 \\
Catalão & 574.868 & 3,97 & 570.631 & 3,46 \\
Meia Ponte & 1.528 .494 & 10,56 & 1.522 .996 & 9,24 \\
Pires do Rio & 400.325 & 2,77 & 452.592 & 2,74 \\
Quirinópolis & 1.310 .604 & 9,05 & 1.206 .389 & 7,32 \\
Sudoeste de Goiás & 2.079 .040 & 14,36 & 2.302 .653 & 13,97 \\
Vale do Rio dos Bois & 937.278 & 6,47 & 1.031 .467 & 6,26 \\
Totais & 14.476 .565 & 100,00 & 16.488 .390 & 100,00 \\
\hline Fonyyyy
\end{tabular}

Fonte: Dados dos Censos Agropecuários trabalhados pelo autor. 
A microrregião de Meia Ponte se mantém em segundo lugar $(10,56 \%)$ mas sua importância parece declinante. O crescimento do seu rebanho foi de $8,43 \%$ enquanto que no Sudoeste de Goiás, para citar um exemplo, o rebanho cresceu $21,64 \%$ no período.

Os municípios detentores dos maiores rebanhos, em 1995, são: Crixás e Rio Verde.

A área com pastagens, no período em análise, cresceu a taxas menores quando confrontada com a expansão do número de cabeças. Assim, o Estado de Goiás está aumentando a quantidade de bovinos por hectare.

Não necessariamente, as localidades com maior área de pastagens e/ou rebanho são as mais produtivas. Verifica-se, por exemplo, que o Sudoeste de Goiás tem um baixo índice de produtividade $(0,47$ cabeças por hectare, na média do período em estudo). Em outras regiões, como Anicuns e Anápolis (com baixa participação da área com pastagens), a produtividade média para o periodo foi de 1,24 e 1,10 bovino por hectare, respectivamente. $\mathrm{Na}$ verdade, essas duas microrregiões são exceção. Elas estão se especializando em novos sistemas de criação. As demais microrregiões, fora do Sul e Centro do Estado, são ineficientes na criação. Nelas o gado é criado extensivamente, principalmente na bacia do Rio Araguaia e na divisa do Estado do Tocantins.

\subsubsection{Utilização do trabalho na agricultura}

Nas regiões mais pobres a prática da agricultura de subsistência é corriqueira, utilizando mais o fator trabalho que o capital. Também, o tipo de cultura predominante na região pode levar a maior ou menor ocupação do trabalho. Em Goiás, algumas culturas, como o café e as hortaliças não têm ainda condições de substituir postos de trabalhos por máquinas eficientes e baratas.

Segundo Curi (1997) uma das características do Programa de Desenvolvimento do Cerrado (POLOCENTRO) foi o aumento do emprego nas áreas 
inexploradas. De acordo com esse pesquisador, o fator trabalho cresceu em Goiás, até 1985, decrescendo nos anos seguintes.

Barros \& Geraldine (1987) constataram que o desenvolvimento numa região de fronteira contribuiria para maior utilização de mão-de-obra caso aumentasse o numero de pequenas propriedades agrícolas. Se ocorresse aumento dos latifúndios ou das áreas com pastagens, haveria diminuição no uso do fator.

Müller \& Martine (1997) argumentam que o processo de modernização da agricultura brasileira nos anos 60 e 70 aumentou a produção agropecuária simultaneamente ao êxodo rural. Porém, na década de 80 o ritmo de crescimento da população e a força de atração urbana fizeram com que a migração campo-cidade fosse menor.

Em 1970, Goiás empregava 394.949 trabalhadores entre homens, mulheres e crianças. Este número cresce até 1985 quando atinge 616.336 empregados. De 1985 a 1995, há uma queda de $23,47 \%$ : somente 471.657 pessoas encontraram ocupação na agricultura. A Tabela 20 mostra as microrregiões e os municípios que mais empregaram o fator trabalho. 
Tabela 20. Microrregiões e Municípios que mais empregaram pessoas na agricultura do Estado de Goiás, 1970 - 1995.

\begin{tabular}{|c|c|c|c|c|}
\hline Ano & Microrregião & Quantidade & Municípios & Quantidade \\
\hline \multirow{3}{*}{1970} & Ceres & 47.507 & Rio Verde & 15.182 \\
\hline & Meia Ponte & 39.167 & Ceres & 10.152 \\
\hline & Sudoeste de Goiás & 36.873 & Itumbiara & 9.512 \\
\hline \multirow{3}{*}{1975} & Porangatu & 55.123 & Niquelândia & 16.513 \\
\hline & Ceres & 52.913 & Rio Verde & 15.032 \\
\hline & Entorno de Brasília & 47.812 & Quirinópolis & 13.559 \\
\hline \multirow{3}{*}{1980} & Entorno de Brasília & 59.610 & Rio Verde & 13.559 \\
\hline & Porangatu & 56.365 & Crixás & 12.915 \\
\hline & Sudoeste de Goiás & 49.948 & Pirenópolis & 12.751 \\
\hline \multirow{3}{*}{1985} & Porangatu & 65.052 & Niquelândia & 15.915 \\
\hline & Entorno de Brasília & 63.307 & Goiás & 13.828 \\
\hline & Ceres & 61.916 & Rio Verde & 13.586 \\
\hline \multirow{3}{*}{1995} & Ceres & 47.626 & Rio Verde & 8.356 \\
\hline & Sudoeste de Goiás & 43.953 & Silvânia & 8.256 \\
\hline & Entorno de Brasília & 42.451 & Santa Helena de Goiás & 7.499 \\
\hline
\end{tabular}

Fonte: Dados dos Censos Agropecuários trabalhados pelo autor.

A Tabela 21 evidencia o nível de emprego de homens e de mulheres no setor meio agrícola. Na agricultura goiana, predominam os homens, porém as mulheres vêm participando de modo crescente. Os baixos salários pagos no setor fazem com que mais pessoas de uma família sintam necessidade de complementar a renda familiar. $O$ Anuário Estatístico do IBGE de 1995 indica, para Goiás, que o salário médio mensal dos homens era de $\mathrm{R} \$ 175,00$, enquanto as mulheres recebiam em média $\mathrm{R} \$ 94,00 /$ mês. 
Tabela 21. Quantidade de homens e mulheres empregados no setor agrícola do Estado de Goiás, 1970 - 1995.

\begin{tabular}{cccccc}
\hline Anos & $\begin{array}{l}\text { Total de } \\
\text { Homens }\end{array}$ & $\%$ & $\begin{array}{c}\text { Total de } \\
\text { Mulheres }\end{array}$ & $\%$ & $\begin{array}{c}\text { Total de } \\
\text { Empreg. }\end{array}$ \\
\hline 1970 & 321.735 & 81,46 & 73.214 & 18,54 & 394.949 \\
1975 & 380.902 & 76,45 & 117.328 & 23,55 & 498.230 \\
1980 & 390.323 & 71,76 & 153.614 & 28,24 & 543.937 \\
1985 & 438.491 & 71,14 & 177.845 & 28,86 & 616.336 \\
1995 & 337.073 & 71,47 & 134.584 & 28,53 & 471.657 \\
\hline
\end{tabular}

Fonte: Dados dos Censos Agropecuários Trabalhados pelo autor.

Os Censos Agropecuários disponibilizam estatísticas de menores de 14 anos, de ambos os sexos, com ocupação na agricultura. É uma situação indesejável, porém ainda real na economia brasileira. A Constituição brasileira garante ao menor o direito de uma infância com educação e saúde. Mas, as condições financeiras das familias e do Estado, obrigam as crianças a renunciar esse direito em prol do seu próprio sustento e de seus familiares. Ver Tabela 22.

Tabela 22. Porcentagens de menores no emprego agrícola do Estado de Goiás, 1970 1995.

\begin{tabular}{lccrrcc}
\hline Anos & $\begin{array}{c}\text { Total de } \\
\text { Homens }\end{array}$ & $\begin{array}{c}\text { Total de } \\
\text { Homens } \\
\text { Menores }\end{array}$ & $\%$ & $\begin{array}{c}\text { Total de } \\
\text { Mulheres }\end{array}$ & $\begin{array}{c}\text { Total de } \\
\text { Mulheres } \\
\text { Menores }\end{array}$ & $\%$ \\
\hline 1970 & 321.735 & 29.127 & 9,05 & 73.214 & 10.784 & 14,73 \\
1975 & 380.902 & 52.006 & 13,65 & 117.328 & 26.535 & 22,62 \\
1980 & 390.323 & 52.626 & 13,48 & 153.614 & 35.420 & 23,06 \\
1985 & 438.491 & 53.683 & 12,24 & 177.845 & 37.583 & 21,13 \\
1995 & 337.073 & 28.158 & 8,35 & 134.584 & 23.230 & 17,26 \\
\hline
\end{tabular}

Fonte: Dados dos Censos Agropecuários trabalhados pelo autor.

Em 1970, Goiás empregou 29.127 menores do sexo masculino e 10.784 do sexo feminino. $\mathrm{O}$ ano de 1975 foi o que mais empregou menores do sexo masculino e 
1980 utilizou mais o trabalho de menores do sexo feminino. No sub-período $1975-$ 1995, constata-se uma expressiva redução da utilização do trabalho de crianças na agricultura goiana, tanto em números absolutos como relativos. No caso de crianças do sexo feminino tal redução revela-se mais sensível a partir de 1980.

A Tabela 23 traz uma comparação entre a utilização do trabalho de adultos e de crianças na agricultura de Goiás e do Brasil.

Tabela 23. Comparação da utilização de Trabalho infantil na agricultura brasileira e goiana, $1970-1995$.

\begin{tabular}{rlrlllrrr}
\hline Ano & & $\begin{array}{l}\text { Total de } \\
\text { Homens }\end{array}$ & $\begin{array}{l}\text { Homens } \\
\text { Menores }\end{array}$ & $\begin{array}{l}\text { Total de } \\
\text { Mulheres }\end{array}$ & $\begin{array}{l}\text { Mulheres } \\
\text { Menores }\end{array}$ & $\begin{array}{l}\text { Total de } \\
\text { Menores }\end{array}$ & $\begin{array}{l}\text { Total de } \\
\text { Pessoas } \\
\text { Empregadas }\end{array}$ \\
\hline 1970 & Brasil & 11.929 .099 & 1.804 .042 & 5.652 .990 & 1.096 .288 & 2.900 .330 & 17.582 .089 \\
& Goiás & 321.735 & 29.127 & 73.214 & 10.784 & 39.911 & 394.949 \\
1975 & Brasil & 12.898 .021 & 2.498 .732 & 7.447 .671 & 1.891 .482 & 4.390 .214 & 20.345 .692 \\
& Goiás & 380.902 & 52.006 & 117.328 & 26.535 & 78.541 & 498.230 \\
1980 Brasil & 14.274 .724 & 2.260 .526 & 6.835 .160 & 1.471 .380 & 3.731 .906 & 21.109 .884 \\
& Goiás & 390.323 & 52.626 & 153.614 & 35.420 & 88.046 & 543.937 \\
1985 Brasil & 15.557 .399 & 2.445 .853 & 7.837 .482 & 1.662 .465 & 4.108 .318 & 23.394 .881 \\
& Goiás & 438.491 & 53.683 & 177.845 & 37.583 & 476.074 & 616.336 \\
1995 & Brasil & 11.978 .392 & 1.392 .136 & 5.952 .336 & 1.043 .527 & 2.435 .663 & 17.930 .728 \\
& Goiás & 337.073 & 28.158 & 134.584 & 23.230 & 51.388 & 471.657 \\
\hline
\end{tabular}

Fonte: Censos Agropecuários e Dados da Pesquisa.

Apesar de Goiás não ter utilizado mais que $3 \%$ de força de trabalho infantil, os números chegam a ser alarmantes para o país: 2,9 milhões de menores empregados em 1970; 4,4 milhões em 1975; 3,7 milhões em 1980; 4,1 milhões em 1985 e 2,4 milhões em 1995/96. Sensível melhoria é observada no sub-período 1985 - 1995 ($41,46 \%)$. 


\subsubsection{Produtividade da Terra}

No quinquênio 1970/75 ocorreu o crescimento de $121,77 \%$ na produtividade da terra em reais de 1995 , ao atingir $\mathrm{R} \$ 98,07$ por hectare (ver Tabela 4).

Nesse período, os municípios de Santa Helena de Goiás, Caturaí e Goiânia foram os mais destacados com $\mathrm{R} \$ 624,46, \mathrm{R} \$ 497,03$ e $\mathrm{R} \$ 472,00$ por hectare. Entre as microrregiões, Anápolis, Anicuns e Goiânia foram aquelas onde os agricultores alcançaram maior produtividade com $\mathrm{R} \$ 283,62$, $\mathrm{R} \$ 270,55$ e $\mathrm{R} \$ 191,38 /$ ha.

No sub-período de 1975-1980, o crescimento da produtividade da terra foi de $27,05 \%$ para o Estado como um todo, atingindo a média de $\mathrm{R} \$ 124,60$. Porém, alguns municípios como Goiânia, Joviânia e Santa Helena de Goiás destacaram-se com mais de 500 reais por hectare.

Em 1985, o Estado alcança $\mathrm{R} \$ 130,58 /$ ha, o maior valor obtido no período em estudo. Representa um crescimento de 4,8\% em relação a 1980 . Os municípios de maior produtividade da terra foram: Inhumas ( $\$$ \$692,92); Maurilândia $(\mathrm{R} \$ 591,80)$ e Nerópolis $(\mathrm{R} \$ 568,97)$.

O fato mais grave para a agricultura goiana foi a queda de $28 \%$ do rendimento por hectare de 1985 a 1995, graças ao efeito preço.

Em resumo, a produtividade da terra, medida em unidades monetárias, cresceu até 1985 e dai para frente decresce. Em 1995, o agricultor goiano passou a ganhar menos por hectare do que ganhava em 1975 .

\subsubsection{Nível de Investimentos na Agricultura}

Belik (1998) mostra que o crédito rural esteve em alguns anos da década de 70 acima do PIB agropecuário. Porém, na década de 90 essa tal relação passa a ser algo próximo de $20 \%$ do PIB do setor. 
Os investimentos são necessários à produção na medida em que renovam e/ou aumentam a capacidade produtiva instalada. Os investimentos podem refletir crescimento do parque industrial, construção de novos edificios, compra de novas máquinas, etc. Ou ainda na reposição do desgaste físico e tecnológico do capital produtivo.

Quando o investimento cresce pouco ou permanece constante, não se consegue repor a depreciação física ou tecnológica dos bens de capital do setor ${ }^{12}$. Assim, o sucateamento desses bens e da atividade torna-se inevitável uma vez que os custos para tornar a produção competitiva poderão inviabilizá-la. Ver Tabela 24.

Tabela 24. Valor e evolução do investimento e da produção da agricultura, em mil reais, Brasil, $1970-1995$.

\begin{tabular}{lrrrc}
\hline Ano & Produção & Investimento & $\begin{array}{c}\text { Cresc. da produção no } \\
\text { período }\end{array}$ & $\begin{array}{c}\text { Cresc. dos investimento } \\
\text { no período }\end{array}$ \\
\hline 1970 & 29.430 .509 & 5.242 .950 & - & - \\
1975 & 61.416 .558 & 13.912 .625 & 108,68 & 165,36 \\
1980 & 79.104 .098 & 29.700 .013 & 28,8 & 113,48 \\
1985 & 92.556 .376 & 51.984 .938 & 17,01 & 75,03 \\
1995 & 47.788 .242 & 7.722 .635 & $-48,37$ & $-85,14$ \\
\hline
\end{tabular}

Fonte: Dados dos Censos Agropecuários trabalhados pelo autor.

A produção agrícola e os investimentos na agricultura brasileira tiveram significativo crescimento durante a década de 70. De 1970 a 1975, a produção salta de 29,4 bilhões de reais para 61,4 bilhões registrando crescimento de 108,68\%. Quanto aos investimentos, elevam-se em 165,36\% passando de 5,2 bilhões para 13,9 bilhões de reais. No último quinquênio dos anos 70 , as crises internacionais e a inflação interna

\footnotetext{
${ }^{12}$ Pode-se, aqui, contra argumentar que os novos equipamentos, máquinas etc. têm uma vida útil mais longa que as anteriores e portanto não necessariamente precisam de constantes renovações. Esta pesquisa parte da hipótese de que isso não ocorre porque uma máquina mais durável (tecnologicamente superior) deve ser mais cara pelo menos por algum tempo.
} 
desaqueceram o setor agrícola. O crescimento da produção foi de $28,8 \%$, mas os investimentos mantiveram-se em alta $(113,48 \%)$.

$\mathrm{Na}$ início da década de 80 , as crises econômicas provocam a recessão da economia nacional mas os níveis de produto agropecuário e investimento mantiveram-se em expansão. O problema se agrava no período compreendido entre 1985 e 1995 . A produção cai $48,37 \%$ e os investimentos diminuem $85,14 \%$.

O comportamento da produção e do investimento é semelhante no Estado de Goiás. Ver Tabela 25.

Tabela 25. Valor e evolução do investimento e da produção da agricultura, em mil reais, Estado de Goiás, 1970 - 1995.

\begin{tabular}{lcccc}
\hline Ano & Produção & Investimento & Cresc. Produção & Cresc. investimentos \\
\hline 1970 & 1.076 .069 & 258.984 & - & - \\
1975 & 2.715 .630 & 924.778 & 152,37 & 257,08 \\
1980 & 3.636 .518 & 2.154 .218 & 33,91 & 132,94 \\
1985 & 3.899 .655 & 1.946 .599 & 7,24 & $-9,64$ \\
1995 & 2.582 .846 & 624.520 & $-33,77$ & $-67,92$ \\
\hline
\end{tabular}

Fonte: Dados dos Censos Agropecuários trabalhados pelo autor.

A agricultura em solos de cerrado exige altos investimentos em preparo do solo e melhoria de variedades. Para o desenvolvimento da agricultura goiana foram necessários maciços investimentos, principalmente em calagem e adubação.

Analisando os investimentos agrícolas e pecuários no Estado, o Sul Goiano e o Centro Goiano são as mesorregiões de maior destaque. Desde 1970 , mais de $70 \%$ dos investimentos agropecuários são realizados nessas localidades. 
Em se tratando de microrregiões, Sudoeste de Goiás e Meia Ponte são as que mais têm investido no setor agrícola. Cerca de $23 \%$ dos investimentos totais do Estado estão nessas duas microrregiões.

Entre os municípios, Rio Verde esteve sempre entre os três primeiros no período em estudo. Os municípios localizados mais ao sul do Estado são aqueles que mais investem. Somente nos últimos sub-periodos é que aparece com destaque o município de Crixás (pertencente a microrregião de São Miguel do Araguaia, da mesorregião Leste Goiano).

\subsubsection{Evolução da área cultivada por trabalhador e mecanização agrícola}

Monteiro \& Minoga (1969) diziam que o uso da mecanização pode ser condicionado pelas características da região e disponibilidade de crédito. Numa análise microeconômica, a mecanização expulsaria pessoas do campo ao aumentar a área cultivada por trabalhador, mas o aumento da produção gerado com o processo mecânico deve impulsionar o setor não-agrícola para que este absorva o excedente de mão-de-obra no campo.

A relação área-homem apresentou-se em queda até a metade da década de 80 quanto começou a se recuperar. Isso se deve ao fato de a área cultivada ter crescido menos do que a utilização do fator trabalho. Somente a partir de 1985 é que esse índice tem crescimento $(6,08 \%)$ devido a forte contração do emprego.

Em regiões onde predomina a bovinocultura extensiva, o fator trabalho não é tão importante. Já em regiões predominantemente agrícolas, a utilização de mão-de-obra depende da cultura e de eventuais empecilhos ao uso de mecanização. Lavouras como soja e milho não necessitam grande contigente de trabalhadores. As várias fases entre o plantio e a colheita são mecanizadas. Culturas como cana-de-açúcar, café, laranja e algodão demandam uma quantidade maior de mão-de-obra. Também nas regiões de relevo acidentado onde é difícil o acesso das máquinas, torna-se mais intensivo o uso do fator trabalho. 
Quanto às culturas intensivas em mão-de-obra, cabe destaque no Estado apenas o algodão. Entretanto, a produção de algodão tem caído muito e, portanto, liberado enorme contigente de trabalhadores, principalmente no Sudoeste de Goiás.

Ao se analisar o cultivo da terra em 1970, nas microrregiões de São Miguel do Araguaia, Aragarças e no Sudoeste de Goiás, cada trabalhador cultivava 194,00, 142,93 e 138,27 hectares de terras, respectivamente. Essa estrutura se mantém em 1975.

Na década de 80 houve mudança nesse quadro. A microrregião Vale do Rio dos Bois passa a cultivar 227 hectares por trabalhador, seguida de Porangatu com 193,65 e São Miguel do Araguaia, com 172,66 hectares.

Em 1985, cada trabalhador cultivava áreas menores do que em 1980. Em São Miguel do Araguaia 131,47 hectares, no Sudoeste de Goiás 120,59 ha e na Chapada dos Veadeiros, 93,44 hectares por trabalhador.

As principais microrregiões em termos de relação área-homem no ano agrícola de 1995/96 são: São Miguel do Araguaia $(147,75)$ Aragarças $(119,60)$ e o Sudoeste de Goiás $(110,85)$.

A intensificação do uso de máquinas possibilitou o maior cultivo de terras pelos trabalhadores rurais. Neste trabalho, espera-se que o de tratores (em cavalosvapor) seja uma proxy do fator capital.

Segundo Silva et ali (1990), a implantação da indústria de tratores e implementos no Brasil data de 1959, com o Plano Nacional da Indústria de Tratores Agrícolas. Segundo esse autor, havia otimismo quando ao sucesso dessa indústria pois o Brasil dispunha de grandes áreas, ideais para a mecanização. Porém, o ritmo de crescimento da demanda não atingiu as expectativas da indústria. Houve nos últimos anos da década de 80 grande queda das vendas mas isto não significou comprometimento do processo de modernização da agricultura. Para Barros (1999), o 
que ocorreu foi a melhoria tecnológica das máquinas. Elas tornaram-se mais duráveis e potentes.

Em Goiás, a intensificação do uso de tratores foi tardia. Só na década de 80 é que se evidenciou o uso de um número maior de máquinas. Ver Tabela 26.

Tabela 26. Quantidade de tratores empregados na agricultura do Brasil e do Estado de Goiás, 1970 - 1995 .

\begin{tabular}{lcccc}
\hline Anos & Brasil & Goiás & Cresc. Brasil & Cresc. Goiás \\
\hline 1970 & 165.870 & 5.635 & - & - \\
1975 & 323.113 & 13.084 & 94,80 & 132,19 \\
1980 & 545.205 & 24.572 & 68,74 & 87,80 \\
1985 & 665.280 & 33.548 & 22,02 & 36,53 \\
1995 & 803.727 & 43.313 & 20,81 & 29,11 \\
\hline
\end{tabular}

Fonte: Censo Agropecuário e dados da pesquisa.

O Estado de Goiás apresenta ritmos superiores de crescimento do número de tratores do que o Brasil. Isso decorre do crescimento da fronteira agrícola no Estado e dos incentivos à mecanização.

Na Tabela 27 está registrado o número de tratores por microrregião e no Estado de Goiás nos anos censitários. 
Tabela 27. Quantidade de tratores utilizados na agricultura de Goiás. 1970-1995.

\begin{tabular}{lrrrrr}
\hline \multirow{2}{*}{ Microrregiões } & \multicolumn{5}{c}{ Anos } \\
\cline { 2 - 6 } & 1970 & 1975 & 1980 & 1985 & 1995 \\
\hline Anápolis & 554 & 885 & 1.302 & 1.426 & 1.859 \\
Anicuns & 191 & 466 & 605 & 637 & 775 \\
Ceres & 317 & 822 & 1.108 & 1.549 & 1.807 \\
Goiânia & 392 & 653 & 1.067 & 1.291 & 1.732 \\
Iporá & 70 & 145 & 430 & 491 & 695 \\
Entorno de Brasília & 188 & 626 & 1.697 & 2.833 & 3.515 \\
Vão do Paranã & 29 & 122 & 388 & 506 & 873 \\
Aragarças & 31 & 234 & 676 & 766 & 869 \\
Rio Vermelho & 88 & 427 & 1.183 & 1.460 & 1.915 \\
São Miguel do Araguaia & 35 & 303 & 990 & 1.377 & 1.927 \\
Chapada dos Veadeiros & 25 & 47 & 186 & 453 & 639 \\
Porangatu & 73 & 443 & 1.579 & 1.869 & 2.477 \\
Catalão & 133 & 366 & 652 & 1.002 & 2.072 \\
Meia Ponte & 1.511 & 2.759 & 4.351 & 5.383 & 6.644 \\
Pires do Rio & 98 & 199 & 526 & 821 & 1.614 \\
Quirinópolis & 432 & 1.042 & 1.806 & 2.229 & 2.386 \\
Sudoeste de Goiás & 984 & 2.213 & 3.846 & 6.544 & 8.253 \\
Vale do Rio dos Bois & 484 & 1.332 & 2.180 & 2.911 & 3.261 \\
Total do Estado & 5.635 & 13.084 & 24.572 & 33.548 & 43.313 \\
\hline
\end{tabular}

Fonte: Dados dos Censos Agropecuários trabalhados pelo autor.

Dentre os municípios, Itumbiara (com 514 tratores), Rio Verde (446) e Santa Helena de Goiás (347) apresentam maior uso de mecanização em 1970. Em 1975, Itumbiara já utilizava 990 tratores, seguido de Rio Verde com 879 e Paraúna com 705.

Na década de 80, o município de Rio Verde torna-se o mais mecanizado do Estado. Foram registrados no Censo Agropecuário daquele ano 1.438 tratores. Logo em seguida, vêm os municípios de Itumbiara (1.250) e Quirinópolis (815). Em 1985, Rio Verde utilizava 2.343 tratores. Itumbiara registra uma redução de 117 tratores. Abrigou esse município 1.133 tratores. $O$ terceiro município com maior número de tratores é Quirinópolis com 1.095.

O mesmo fenômeno que ocorre a Itumbiara em 1985, assola Rio Verde em 1995. Houve queda do número de tratores para 2.137 unidades. O segundo maior 
município em uso de tratores é Jataí com 1.277, seguido por Goiatuba com 1.207. Itumbiara e Quirinópolis utilizam apenas 981 e 813 tratores, respectivamente. Uma possível explicação seria a queda do valor da produção agrícola nesses municípios e no Estado.

\subsection{Educação e crescimento da população brasileira e goiana de 1970 a 1991}

A tabela 28 compara os níveis populacionais e educacionais do Brasil de 1970 a 1991.

Tabela 28. População brasileira e população de cinco anos ou mais alfabetizada no Brasil, 1970 - 1991.

\begin{tabular}{lccc}
\hline Anos & População total & População alfabetizada & Nível de alfabetização \\
\hline 1970 & 79.218 .612 & 44.739 .730 & 43,52 \\
1980 & 102.579 .006 & 69.703 .993 & 67,95 \\
1991 & 130.283 .402 & 95.352 .354 & 73,19 \\
\hline
\end{tabular}

Fonte: Dados dos Censos Demográficos do IBGE trabalhados pelo autor.

Em 1970, o Brasil abrigava em seu território 79,2 milhões de habitantes. Destes, 44,7 milhões eram alfabetizados. Ao longo da década de 70 , houve o crescimento tanto da população quanto da alfabetização. O país registra, em $1980,102,6$ milhões de habitantes, sendo 69,7 milhões de alfabetizados, ou $67,95 \%$ da população.

Em 1991, a população chega a 130,3 milhões e ao mesmo tempo, 73,19\% da mesma sabendo ler e escrever. Apesar do nível de alfabetização ter crescido no Brasil, ainda é modesto frente aos de outros países ${ }^{13}$

O Estado de Goiás, apesar de sua extensão territorial, não abriga uma grande população. Seu nível de alfabetização do Estado supera o do Brasil. Ver tabela 29.

\footnotetext{
${ }^{13}$ Para maiores detalhes, ver Souza, 1999.
} 
Tabela 29. População e nível de alfabetização em Goiás, 1970 - 1991.

\begin{tabular}{lccc}
\hline Anos & População Total & População Alfabetizada & Nível de Alfabetização (\%) \\
\hline 1970 & 2.051 .645 & 1.075 .604 & 52,43 \\
1980 & 2.628 .181 & 1.772 .473 & 67,44 \\
1991 & 3.573 .388 & 2.794 .263 & 78,20 \\
\hline
\end{tabular}

Fonte: Censos Demográficos do IBGE - vários números e Dados Trabalhados pelo autor.

Em 1970, havia 1,1 milhão de goianos alfabetizados para a população de 2 milhões. Ou seja, 52,43\% dos goianos sabiam ler e escrever. A população do Estado atinge 2,6 milhões em 1980 e 1,8 milhão são alfabetizados (67,44\%). Esta última cifra passa para 2,8 milhões em 1991 numa população de 3,6 milhões.

A população brasileira cresceu na década de 70 a uma taxa de $2,95 \%$ ao ano ou $29,49 \%$ no decênio 1970 a 1980 . Já na década de 80 , há um declínio desse crescimento. A população aumenta a uma taxa de $2,7 \%$ ao ano. Essa tendência baixista não se verifica em Goiás. De 1970 a 1980 a população cresce $28,10 \%$ e na década de 80 a $35,96 \%$.

Dois fatores podem estar contribuindo para isso. A taxa de fecundidade em Goiás pode ser maior que no Brasil ou, o que é mais provável, o Estado atraiu contingentes populacionais de outros estados.

A tabela 30 registra a distribuição da população total e da população alfabetizada nos setores urbano e rural do Estado nos três últimos Censos Demográficos disponiveis à época. 
Tabela 30. Evolução da população rural e urbana e nivel de alfabetização no Estado de Goiás, $1970-1991$.

\begin{tabular}{ccccccc}
\hline & Pop. Urb. & Alfab. Urb. & $\begin{array}{c}\text { Nível Alfab. } \\
(\%)\end{array}$ & Pop. Rur. & Alfab. Rur. & $\begin{array}{c}\text { Nível Alfab. } \\
(\%)\end{array}$ \\
\hline 1970 & 972.352 & 656.776 & 67,54 & 1.079 .293 & 418.830 & 38,81 \\
1980 & 1.815 .506 & 1.343 .977 & 74,03 & 812.675 & 428.496 & 52,73 \\
1991 & 2.896 .890 & 2.349 .459 & 81,10 & 676.498 & 444.804 & 65,75 \\
\hline
\end{tabular}

Fonte: Dados dos Censos Demográficos do IBGE trabalhados pelo autor.

Percebe-se, claramente, o inchaço das cidades e um declínio do número de pessoas no meio rural. Em 1970, 972.352 goianos residiam nas cidades. Esse número passa para 1,8 milhão em 1980 e 2,8 milhões em 1991. Já no campo, a situação se inverte: 1 milhão em 1970 e 676.498 em 1991.

O nível de alfabetização é maior no setor urbano. Nota-se que $67,54 \%$ da população eram alfabetizados em 1970. Esse percentual cresce para 74,03\%, em $1980 \mathrm{e}$ $81,10 \%$ em 1991. No campo, as proporções são mais baixas: $38,81 \%$, em 1970; $52,73 \%$ em 1980 e $65,75 \%$ em 1991.

Monteiro \& Minoga (1969) já se preocupavam com a saída de mão-de-obra desqualificada do campo. Para Hoffmann (1994), a escolaridade é um condicionante do rendimento. $\mathrm{O}$ aumento da escolaridade das pessoas ocupadas na agricultura de Goiás pode ser defendido mesmo sem considerar seus efeitos benéficos sobre o rendimento, pois se trata de uma condição para o pleno exercício da cidadania. Esse último autor constatou que, em 1990, aproximadamente $1 / 3$ das pessoas ocupadas na agricultura do Estado não tinham completado 1 ano de escolaridade e $83,9 \%$ não tinham ultrapassado 4 anos. 


\subsection{Metafunção de produção para o Estado de Goiás}

Estimou-se uma metafunção de produção agregada para a agropecuária do Estado de Goiás no ano de 1995/96, com base nos dados divulgados pelo Censo Agropecuário do IBGE.

Cabe ressaltar que o segmento de pecuária, principalmente o de bovinos, tem predomínio entre os demais subsetores da agricultura goiana. Com base nos resultados encontrados e descritos anteriormente, percebe-se que no Estado, grande parte dos fatores de produção estão alocados na pecuária: $66 \%$ dos tratores, $73 \%$ da mão-de-obra e $70 \%$ das terras. Porém, o valor da produção animal corresponde a $53 \%$ do total produzido. A partir dessas informações, é recomendável a estimação de dois modelos, um para cada segmento. Isso foi feito. Porém a falta de informação mais detalhada para cada subsetor dificultou muito a obtenção de bons resultados. Muitos dos coeficientes encontrados, inicialmente, apesar de estatisticamente significativos, não tinham explicação ou coerência econômica.

Assim sendo, selecionou-se um só modelo com as variáveis representativas dos fatores terra, trabalho, capital, insumos modernos e capital humano. Apenas os fatores terra e insumos modernos foram desagregados. Outra razão foi o melhor ajustamento obtido em termos de presença ou não de multicolinearidade no modelo. Vale ressaltar que a função estimada permite mensurar os efeitos da área com lavouras e com pastagens sobre a produção. Ver Tabela 31 . 
Tabela 31. Coeficientes de regressão e valores do teste " $t$ " para as variáveis da metafunção de produção.

\begin{tabular}{lcc}
\hline Variáveis & Coeficientes & Valores de t (students) \\
\hline Intercepto & $0,426^{\mathrm{ns}}$ & 0,63 \\
$\mathrm{X}_{1}$ (trabalho) & $0,113^{*}$ & 0,05 \\
$\mathrm{X}_{2}$ (capital) & $0,339^{*}$ & 0,12 \\
$\mathrm{X}_{3}$ (área com lavouras) & $0,124^{*}$ & 0,04 \\
$\mathrm{X}_{4}$ (área com pastagens) & $0,072^{* *}$ & 0,04 \\
$\mathrm{X}_{5}$ (insumos mod. Agri) & $0,202^{*}$ & 0,04 \\
$\mathrm{X}_{6}$ (insumos mod. Pec.) & $0,429^{*}$ & 0,05 \\
$\mathrm{X}_{7}$ (educação) & $0,211^{* * *}$ & 0,15 \\
Coeficiente de determinação $\left(\mathrm{R}^{2}\right)=90,50 \%$ & \\
\hline
\end{tabular}

Fonte: Dados trabalhados pelo autor.

Nota: ns = não significativo

* significativo ao nivel de $1 \%$.

** significativo ao nível de $10 \%$.

*** significativo ao nível de $20 \%$.

O modelo estimado inclui como variável dependente o valor da produção agropecuária, em mil reais por município. As variáveis independentes são: $\left(\mathrm{X}_{1}\right)$ representativa do fator trabalho, em equivalente-homem por município; $\left(\mathrm{X}_{2}\right)$ é o fator capital, medido pela potência média dos tratores empregados no setor agropecuário de cada município; $\left(\mathrm{X}_{3}\right)$ representando as terras em lavouras, hectares por município; $\left(\mathrm{X}_{4}\right)$ as terras com pastagens, em hectares por município; $\left(\mathrm{X}_{5}\right)$ como insumos modernos do segmento agrícola, medidos pelo valor das despesas com insumos nas lavouras, em mil reais por município; e, $\left(\mathrm{X}_{6}\right)$ insumos modernos na pecuária, é o valor das despesas com insumos na produção animal, em mil reais por município. O capital humano na agropecuária goiana é estimado pela variável educação $\left(\mathrm{X}_{7}\right)$, escolaridade média da população rural por município.

O coeficiente de determinação do modelo foi alto, sugerindo que $90,50 \%$ das variações na variável dependente podem ser explicadas pelas variáveis selecionadas.

A análise de variância da regressão mostrou-se altamente significativa. $O$ teste $\mathrm{F}$ de Snedecor é significativo ao nível de $1 \%$. Além do mais, segundo o teste $\mathrm{t}$ de 
Student, as variáveis são significativas ao nível de $5 \%$, com exceção de terra com pastagens $\left(\mathrm{X}_{4}\right)$, significativa ao nível de $10 \%$ e educação $\left(\mathrm{X}_{7}\right)$ ao nível de $20 \%$. A baixa densidade de bovinos por hectare pode ser uma possível explicação para o baixo nível de significância dessa variável. Quanto a educação, conforme visto nas tabelas anteriores, é muito reduzida na população rural de Goiás. Uma pessoa com 2,73 anos de estudo tem pouco domínio sobre as técnicas que utiliza e deixa de incorporar inúmeros benefícios à produção. Daí o pequeno efeito da variável sobre a produção.

Os sinais encontrados no modelo são positivos e de acordo com o esperado. A variável extensão, que poderia fazer parte da análise, foi medida experimentalmente como o número de estabelecimentos assistidos pelos serviços de extensão, por município, e não apresentou significância estatística. Uma explicação possível está no pequeno numero de unidades produtivas assistidas. Somente $32,07 \%$ dos estabelecimentos goianos utilizam serviços de extensão.

Segundo o modelo, a agricultura goiana apresenta retornos crescentes à escala. Sendo assim, o aumento proporcional de todos os insumos levaria a aumento mais que proporcional na produção. A soma dos coeficientes de regressão das variáveis convencionais, terra, trabalho, capital e insumos modernos é 1,26.

Todos os coeficientes de regressão foram inferiores a 1 mostrando que os produtores goianos estão produzindo no estagio racional de produção.

Em termos de política agrícola para o Estado de Goiás, um aumento da força mecânica seria preferivel ao aumento do fator trabalho, considerando as respectivas elasticidades de produção.

Em relação à área cultivada, a produção total responderia melhor a incrementos nas áreas destinadas às lavouras do que à pecuária. O coeficiente de elasticidade parcial das áreas com lavouras de $0,124 \%$ contra $0,072 \%$ das áreas com pastagens. 
O aumento de $10 \%$ no uso dos insumos modernos agrícolas aumentaria a produção em 2,02\% e aumento de mesma magnitude nos investimentos para o segmento da pecuária resultaria em $4,29 \%$ de acréscimo na produção agropecuária goiana.

Assim sendo, as decisões de políticas públicas deveriam incentivar o aumento de insumos modernos. Ao mesmo tempo, os investimentos que melhorem a produtividade dos rebanhos, principalmente o bovino, são preferiveis àqueles que sejam apenas de natureza extensiva. A pecuária apresenta problemas sérios quanto aos cuidados sanitários. O Estado ainda não é considerado livre de doenças, como febre aftosa e raiva.

O aumento de $10 \%$ no nível de educação na agricultura goiana provocaria aumento de $2,10 \%$ na produção do setor. Entretanto tal efeito direto da educação não apresenta confiabilidade estatística satisfatória.

O modelo de regressão estimado apresentou problemas de multicolinearidade entre as variáveis terras com lavouras e despesas com insumos modernos para o segmento agrícola. Isso era esperado uma vez que a produção agrícola no cerrado depende de calagem e fertilização química. Mas, de acordo com a metodologia adotada por Judge (1988) o modelo tem multicolinearidade moderada. Os coeficientes de correlação entre as variáveis aparecem na Tabela 32. 
Tabela 32. Matriz de correlação entre as variáveis na forma logarítmica da metafunção de produção para o Estado de Goiás, 1995/96.

\begin{tabular}{lccccccc}
\hline & Trabalho & Capital & Ter. lav. & Ter. past. & Ins. agric & Ins. pec. & Educ. \\
\hline Y & 0,73 & 0,34 & 0,81 & 0,67 & 0,87 & 0,88 & 0,26 \\
Trabalho & 1 & 0,09 & 0,69 & 0,67 & 0,63 & 0,70 & 0,04 \\
Capital & & 1 & 0,26 & 0,27 & 0,34 & 0,25 & 0,06 \\
Ter. lav. & & & 1 & 0,51 & 0,88 & 0,63 & 0,17 \\
Ter. past. & & & & 1 & 0,49 & 0,71 & $-0,15$ \\
Ins. Agric. & & & & & 1 & 0,74 & 0,27 \\
Ins. Pec. & & & & & & 1 & 0,28 \\
Educ. & & & & & & & \\
\hline
\end{tabular}

Fonte: Dados trabalhados pelo autor.

Nesse tipo de modelo, ajustado a partir de corte seccional, a presença de heterocedasticidade costuma ocorrer. No entanto, os testes estatísticos realizados não detectaram tal ocorrência.

\subsubsection{Produtividade marginal dos fatores de produção nas microrregiões do Estado}

A Tabela 33 contém os valores das produtividades marginais dos fatores convencionais de produção, especificados no modelo. Tais valores referem-se às microrregiões e ao Estado. Foram obtidos multiplicando os coeficientes de elasticidade parcial de produção $\left(\mathrm{b}_{\mathrm{i}}\right)$ pela produtividade médias dos fatores $\left(\mathrm{Y} / \mathrm{X}_{\mathrm{i}}\right)$. 
Tabela 33. Produtividade marginal nas principais microrregiões do Estado de Goiás. 1995.

\begin{tabular}{lcccccc}
\hline Microrregião/Estado & $\mathrm{X}_{1}$ & $\mathrm{X}_{2}$ & $\mathrm{X}_{3}$ & $\mathrm{X}_{4}$ & $\mathrm{X}_{5}$ & $\mathrm{X}_{6}$ \\
\hline Anápolis & 7,25 & $12.772,61$ & 4,02 & 0,32 & 46,89 & 63,19 \\
Anicuns & 15,12 & $10.675,47$ & 7,50 & 0,42 & 102,05 & 145,65 \\
Ceres & 6,31 & $11.868,70$ & 3,08 & 0,19 & 41,13 & 101,49 \\
Goiânia & 11,59 & $12.756,54$ & 7,45 & 0,47 & 60,55 & 48,23 \\
Iporá & 22,41 & $12.593,74$ & 19,95 & 0,34 & 362,43 & 223,21 \\
Entorno de Brasília & 7,45 & $11.533,81$ & 1,57 & 0,11 & 15,87 & 69,63 \\
Vão do Paranã & 17,55 & $12.563,57$ & 10,98 & 0,22 & 207,96 & 333,06 \\
Aragarças & 34,04 & $11.381,41$ & 24,98 & 0,25 & 394,29 & 175,55 \\
Rio Vermelho & 14,98 & $11.237,90$ & 12,46 & 0,12 & 94,95 & 74,43 \\
São Miguel do Araguaia & 20,01 & $10.221,51$ & 20,83 & 0,11 & 140,49 & 64,31 \\
Chapada dos Veadeiros & 26,43 & $11.332,54$ & 12,79 & 0,25 & 271,62 & 634,93 \\
Porangatu & 8,59 & $11.648,69$ & 5,80 & 0,11 & 77,14 & 131,18 \\
Catalão & 16,01 & $10.985,56$ & 2,08 & 0,20 & 21,65 & 89,15 \\
Meia Ponte & 7,45 & $10.706,11$ & 0,93 & 0,14 & 9,86 & 45,47 \\
Pires do Rio & 13,43 & $11.117,25$ & 3,40 & 0,32 & 37,81 & 89,40 \\
Quirinópolis & 15,87 & $9.993,33$ & 6,19 & 0,15 & 67,23 & 79,97 \\
Sudoeste de Goiás & 7,91 & $9.149,13$ & 0,52 & 0,07 & 4,54 & 38,92 \\
Vale do Rio dos Bois & 12,08 & $10.603,35$ & 1,52 & 0,20 & 14,29 & 85,73 \\
\hline Estado & 11,78 & $11.200,01$ & 2,71 & 0,17 & 27,34 & 84,41 \\
\hline
\end{tabular}

Fonte: Dados trabalhados pelo autor.

São expressivas as diferenças de produtividade marginal entre as microrregiões e o Estado. Nas localidades onde o fator é mais utilizado sua produtividade marginal tende a ser menor. Como exemplo disso, as microrregiões do Sudoeste de Goiás (especializada em lavouras) e Chapada dos Veadeiros (com predominância da pecuária) merecem destaque. As produtividades marginais de $\mathrm{X}_{3}$ e $\mathrm{X}_{4}$ estimadas para Sudoeste de Goiás e Chapada dos Veadeiros, respectivamente, são inferiores as produtividades marginais desses fatores nas demais regiões. 


\section{CONCLUSÃo}

Em período anterior ao analisado nesta pesquisa, o Estado de Goiás era considerado região típica de criação extensiva de bovinos. A partir dos anos setenta, porém, os incentivos governamentais e o desenvolvimento de variedades adaptadas às condições do cerrado propiciaram a implantação de enormes áreas cultivadas com lavouras comerciais no Estado. Nesse contexto, as microrregiões localizadas ao sul do território goiano merecem referência especial, particularmente nos casos de Sudoeste de Goiás e Meia Ponte. Estas, souberam aliar a fertilidade natural de seus solos à proximidade de grandes centros urbanos do país para se transformarem no principal pólo agroindustrial do Estado.

Desde logo, as atividades agrícolas - capital intensivas e dependentes de financiamento externo - passaram a mostrar altas taxas de crescimento e, progressivamente, o setor agropecuário foi-se transformando e diversificando. Com efeito, nos anos setenta, a produção setorial cresceu a altíssimas taxas, sob a forte influência do uso dos fatores terra, trabalho e capital. Sem esquecer, também, que nesse período os preços das commodities no mercado internacional eram muito altos.

O mesmo dinamismo não se nota a partir dos anos 80 , e em especial após o Plano Cruzado. Na décadas de oitenta e noventa, as taxas de crescimento do setor foram modestas, culminando com taxas negativas em 1995. Além dos baixos preços no mercado internacional, os sucessivos planos econômicos e as elevadas taxas de inflação interna provocaram clima de indefinição e turbulência em toda a economia brasileira. 
Os resultados desta pesquisa sugerem ter ocorrido em Goiás, a partir de 1985, uma acentuada reestruturação do processo produtivo na agricultura. Os agricultores passaram a ser mais avessos ao risco e, em conseqüência, mais seletivos na definição do que e como produzir. Os ganhos de produtividade (com redução de custos) assumiram importante papel nessas decisões. Soja e milho consolidaram suas posições de liderança na produção agrícola estadual; na pecuária de corte observam-se evidências da busca de maior eficácia nas práticas de manejo, sobretudo no que se refere à alimentação do rebanho. Nos mercados de fatores, acentuou-se a substituição de trabalho por capital em decorrência do processo de modernização do setor e da migração rural urbana. Em dez anos, o pessoal ocupado na agropecuária registrou a expressiva redução de $24 \%$ e, ao mesmo tempo, a população rural deve ter diminuído pelo menos $15 \%$. A estrutura fundiária apontou uma certa tendência à concentração, particularmente no grupo de estabelecimentos com área total de 1.000 a menos de 10.000 hectares. Importante também a destacar é o fato de ter aumentado o tamanho médio dos estabelecimentos rurais, de 227 hectares em 1985 para 245 hectares em 1995.

De modo geral, os resultados da análise quantitativa desta pesquisa são coerentes com os obtidos em estudos anteriores sobre funções de produção no Brasil. Tal coerência parece ser mais relevante na natureza das relações insumo - produto estimadas pelo modelo econométrico, ajustado para a agricultura goiana em 1995.

A metafunção de produção estimada indica que as relações insumo - produto são todas positivas e menores que a unidade na agropecuária do Estado de Goiás. Ou seja, os fatores produtivos convencionais estão sendo utilizados no estágio racional, o segundo estágio da produção. Como esperado, o capital humano, aqui representado pela escolaridade média da população rural de 170 dos 232 municípios goianos, tem efeito direto também positivo sobre o valor bruto da produção. Nesse sentido, vale concluir ainda que todas as variáveis explicativas do valor da produção apresentam, segundo o modelo, alta confiabilidade estatística. Exceção feita ao capital humano, possivelmente 
em razão do baixo nível de escolaridade da população rural, na média em torno de 3 anos.

Em termos de política agrícola para o Estado de Goiás, é recomendável priorizar o uso dos recursos capital e insumos modernos. As respectivas elasticidades de produção indicam que esses fatores exercem maior influência sobre o crescimento do produto agropecuário. Aliás, esta recomendação parece consistente com o tipo de agricultura que se pratica em Goiás e com a própria evolução recente deste setor.

As diferenças regionais de produtividade dos fatores, constatadas neste estudo, devem ser consideradas, com o devido cuidado, pelos responsáveis pelas políticas públicas e pelos técnicos do setor. As microrregiões, onde a produtividade marginal dos fatores capital, trabalho, insumos modernos e terra é mais elevada, devem merecer tratamento diferenciado.

Outra questão relevante para as políticas públicas estaduais tem por fundamento a necessidade de valorização da idéia de desenvolvimento rural, ao contrário de se objetivar apenas (ou principalmente) o desenvolvimento do setor agropecuário. Na verdade, a promoção do desenvolvimento rural tem uma conotação muito mais abrangente, passando inclusive por maiores investimentos em capital físico (infraestrutura geral, por exemplo), capital humano (mormente educação e saúde) e geração de empregos não-agrícolas no território rural e nas pequenas cidades do interior. Alguns resultados da análise qualitativa permitem esta última sugestão. 


\section{REFERÊNCIAS BIBLIOGRÁFICAS}

AGROANALYSIS. Carta verde, este não vai ser igual àquele que passou... Instituto Brasileiro de Economia: FGV. V.16, n.4, abril/1996. p.7.

ALVES, E. Os dilemas da política agrícola brasileira. Revista de Economia e Sociologia Rural, v.26, n.1, p.1-22, jan./mar. 1988.

ANDRADE, M.P. Estrutura fundiária, modernização e distribuição da renda na agricultura matogrossense. Piracicaba, 1989. 201p. Dissertação (mestrado) Escola Superior de Agricultura "Luiz de Queiroz", Universidade de São Paulo.

ANDRADE, M.V. Educação e crescimento econômico no Brasil: evidencias empíricas para os Estados Brasileiros - 1970-1995. Texto disponível no site: www.ie.ufrj.br/nuca-wp/mandrade.htm, no dia 23 de março de 1999.

ANUÁRIO ESTATÍSTICO DO BRASIL - 1995, v 55, 1995.

ARAÚJO, P.F.C.; BARROS, G.S.C; MEYER, R.; RASK, R.; SHIROTA, R. Renda, investimento e fontes de financiamento em 330 fazendas do Brasil. Piracicaba, Relatório de Pesquisa n. ${ }^{\circ}$ 10, 38p. Maio de 1991.

ARAÚJO, P.F.C.; SCHUH, G.E. Desenvolvimento econômico e agricultura. Notas de aula da disciplina LES - 780: Desenvolvimento econômico II. Piracicaba, 1998. $75 \mathrm{p}$. 
BACHA, C.J.C. Macroeconomia: conceito, mensuração e evolução dos agregados econômicos brasileiros. Serie Didática D - 83. Piracicaba - São Paulo. Dez/96. $196 \mathrm{p}$.

BACHA, C.J.C. e ROCHA, M.T. O comportamento da agropecuária brasileira, no período de 1987 a 1996. Revista de Economia e Sociologia Rural, v.36, n.1, p.3560 ,jan./mar. 1998.

BARBOSA, M.M.T.L. Oferta agrícola e expectativas racionais. Revista Brasileira de Economia, v.41, n.3, p.275-293, jul./set. 1987.

BARROS, A.L.M. Capital, produtividade e crescimento da agricultura: o Brasil de 1970 a 1995. Piracicaba, 1999. 149p. Tese (doutorado) - Escola Superior de Agricultura Luiz de Queiroz.

BARROS, G.S.C e GERALDINE, D.G. Empregos na fronteira agrícola: o caso da agricultura goiana. Revista de Economia Rural, v.25, n.3, p.347-356, jul./set. 1987.

BELIK, W. Estado, grupos de interesse e formulação de políticas para a agropecuária brasileira. Revista de Economia e Sociologia Rural, v.36, n.1, p.9-34, jan./mar. 1998.

BERTRAN, P. Formação econômica de Goiás. Goiânia, oriente, 1978. 160p.

BONELLI, R. \& FONSECA, R. Ganhos de produtividade e de eficiência: novos resultados para a economia brasileira. Rio de Janeiro, IPEA, 1998. 43p.

CAMPELO, V.B. e KHAN, A.S. Alocação de fatores de produção e mudança tecnológica na agricultura do Estado do Acre. Revista de Economia e Sociologia Rural, v.31, n.3, p.231-245, jul./set. 1993. 
CARVALHO, A.V.; ARANTES, P.F. Tecnologia e produtividade, até quando? Federação da agricultura de Goiás - FAEG. Material disponivel no Site: http://www.faeg.com.br/agroanalise_dez.htm, no dia 16 de abril de 1999.

CARVALHO, J.L. Choques externos e a resposta interna: "semeando vento e colhendo tempestade”. Revista Brasileira de Economia, v.43, n.2, p.139-175, abr./jun. 1989.

CENSO AGROPECUÁRIO - 1970, n² 23, 1970.

CENSO AGROPECUÁRIO - 1975, n² 23, 1976.

CENSO AGROPECUÁRIO - 1980, n² 25, 1980.

CENSO AGROPECUÁRIO - 1985, n² 27, 1985.

CENSO AGROPECUÁRIO - 1995 - 1996, n² 25, 1996.

CENSO DEMOGRÁFICO - 1970, nº 23, 1970.

CENSO DEMOGRÁFICO - 1980, t.4, nº 9, 1980.

CENSO DEMOGRÁFICO - 1991, n² 27, 1991.

CONCEIÇÃO, J.C.P.R. Fronteira de produção estocástica e eficiência técnica na agricultura. Piracicaba, 1998. 108 p. Tese (doutorado) - Escola Superior de Agricultura Luiz de Queiroz.

CONJUNTURA ECONÔMICA. Índice Geral de Preços - Vários números.

CUNHA, A.S.; MÜELLER, C.C.; ALVES, E.R.A. e SILVA, J.E. Uma avaliação da sustentabilidade da agricultura nos cerrados. Brasília: IPEA, 1994. 256p. (Relatório de pesquisa). 
CURI, W.F. Eficiência e fontes de crescimento da agricultura mineira na dinâmica de ajustamento da economia brasileira. Viçosa, 1997. 182p. Tese (doutorado) Universidade Federal de Viçosa.

DIAS, R.S.; BRANDT, S.A; YAMAGUCHI, L.C.T. e LEMOS, J.J.S. Retornos à escala e elasticidade de substituição na agricultura brasileira: uma função de produção translog. Revista de Economia e Sociologia Rural, v.24, n.1, p.23-30, jan./mar. 1986.

DIESEL, T.R.D.; SILVA, L.M.A. e DIESEL, W.R. Formação dos preços de fertilizantes no mercado brasileiro, antes e depois da abertura comercial. Revista de Economia e Sociologia Rural, v.35, n.3, p.9-22, jul./set. 1997.

ENGLER, J.J.C. Análise da produtividade agrícola entre regiões do Estado de São Paulo. Piracicaba, 1978. 132p. Tese (Livre-Docente) - Escola Superior de Agricultura Luiz de Queiroz.

ESTEVAM, L. O tempo da transformação: estrutura e dinâmica da formação econômica de Goiás. Goiânia: centro editorial e gráfico da UFG, 1998. 275p.

FERGUSON, C.E. Microeconomia. Trad. A. G. Barbassa e A. P. Brandão. $15^{\mathrm{a}}$ ed. Rio de Janeiro: Forense Universitária, 1991. 624 p.

FIGUEIREDO, N.M.S. Modernização, distribuição da renda e pobreza na agricultura brasileira, 1975, 1980 e 1985. Piracicaba, 1996. 248p. Tese (doutorado) - Escola Superior de Agricultura "Luiz de Queiroz", Universidade de São Paulo.

GARÓFALO, G.L.; CARVALHO, L.C.P. Teoria microeconômica. São Paulo: Atlas, 1985. 573p.

GIRÃO, J.A. A função de produção de Cobb-Douglas e a análise inter-regional da produção agrícola. Lisboa: Fundação Calouste Gulbenkian, 1965. 117p. 
GRILICHES, Z. Despesas em pesquisa e educação na função de produção agrícola agregada. In: ARAÚJO. P.F.C.; SCHUH, G.E. Desenvolvimento da agricultura: educação, pesquisa e assistência técnica. São Paulo: Pioneira, 1975. Cap. 2, 101116: Investimento em pesquisa.

HAYAMI, Y.; RUTTAN, V.W. Desenvolvimento agrícola: testes e experiência empíricas. Trad. M. V. Von Bulow e J. S. W. Vow Bulow. EMBRAPA, Brasília, 1985. 583p.

HOFFMANN, R. Desigualdade e pobreza na agricultura de Goiás: 1970 - 1990. Revista de Economia e Sociologia Rural, v.32, n.3, p.237-254, jul./set. 1994.

HOFFMANN, R. e KASSOUF, A.L. Modernização e desigualdade na agricultura brasileira. Revista Brasileira de Economia, v.43, n.2, p.273-303, abr./jun. 1989.

HOMEM DE MELO, F. A composição da produção no processo de expansão da fronteira agrícola brasileira. Revista de Economia Política, v.5, n.1, jan./mar. 1985.

HOMEM DE MELO, F. A questão da política de preços para produtos agrícolas domésticos. Revista Brasileira de Economia, v.45, n.3, p.385-396, jul./set. 1991.

HOMEM DE MELO, F. O crescimento agrícola brasileiro dos anos $80 \mathrm{e}$ as perspectivas para os anos 90. Revista de Economia Política, v.10, n.3, jul./set. 1990.

HOMEM DE MELO, F. Tendência de queda nos preços reais de insumos agrícolas. Revista de Economia Política, v.12, n.1, jan./mar. 1992.

ISSLER, J.V.; GONZAGA, G.M. e MORONE, G.C. Educação, investimentos externos e crescimento econômico: evidencias empíricas. Revista de Econometria, v.16, n.2, p.101-127, nov. 1996.

JUDGE, G.G.; HILL, R.C.; GRIFFITHS, W.E.; LÜTKEPOHL, H.; LEE, T. Introduction to the theory and pratice of econometric. New Iork, 1988. 1024p. 
KASSOUF, A.L. Retornos à escolaridade e ao treinamento nos setores urbano e rural do Brasil. Revista de Economia e Sociologia Rural, v.35, n.2, p.59-76, abr./jun. 1997.

KHAN, A.S. e SILVA, L.M.R. Assistência técnica, eficiência na utilização dos fatores de produção e da produtividade diferencial em propriedades rurais. Revista de Economia e Sociologia Rural, v.35, n.2, p.96-115, abr.jun. 1997.

KUZNETS, S. Economic growth and the contribution of agriculture: notes on measurements. In: EICHER, C.; WITT, L. Agriculture in economic development. New York, Mcgraw-hill, 1964. 415p.

LANDIM, J.R.M. Fatores socio-econômicos e eficiência econômica da empresa rural de Piracicaba. Piracicaba, 1972. 107p. Dissertação (mestrado) - Escola Superior de Agricultura "Luiz de Queiroz", Universidade de São Paulo.

LEMOS, M.B. Impactos da abertura comercial da agricultura sobre o desenvolvimento regional brasileiro. Revista de Economia e Sociologia Rural, v.34, n.1 e 2, p.229252, jan./jun. 1996.

LOPES, M.R. O poder das coalizões políticas de grupos de interesse de bloquear o desenvolvimento agrícola. In: TEIXEIRA, E.C. desenvolvimento agrícola na década de 90 e no século XXI. Viçosa: imprensa universitária, 1993. Cap.7, p.105-130.

MONTEIRO, M.J.C. e MINOGA, P.E. A mecanização na agricultura brasileira. Revista Brasileira de Economia, v.23, n.4, p.71-180, out./dez. 1969.

MOREIRA, C.G. Fonte de crescimento das principais culturas do Rio Grande do Norte, 1981-92. Piracicaba, 1996. 109p. Dissertação (mestrado) - Escola Superior de Agricultura “Luiz de Queiroz", Universidade de São Paulo. 
MÜLLER, C.C. e MARTINE, G. Modernização da agropecuária, emprego agrícola e êxodo rural no Brasil - a década de 1980. Revista de Economia Política, v.17, n.3, jul./set. 1997.

NARDIN, M.S.; ARAÚJO, P.F.C. Indicadores do nível de tecnologia na agricultura e estimativa de uma função de produção agregada, 1980. Usp/esalq. 1994. 25p. Relatório parcial do projeto: Uma descrição sócio-econômica da agricultura brasileira.

NICHOLLS, W.H. Paiva e o dualismo tecnológico na agricultura: um comentário. Pesquisa e Planejamento Econômico, Rio de Janeiro, v.3, n.1, p.15-50, mar. 1973.

NOGUEIRA, A.C. Risco e incerteza na combinação de atividades agrícolas nos Estados de Minas Gerais e Goiás. Viçosa, 1974. 58p. Dissertação (mestrado) Universidade Federal de Viçosa.

OLIVEIRA, M.J.C. Rentabilidade privada e social da produção de alimentos na agricultura dos cerrados. Viçosa, 1985. 57p. Dissertação (mestrado) Universidade Federal de Viçosa.

PASSOS, A.T.B. e KHAN, A.S. Política agrícola e desigualdades econômicas e sociais do setor agrícola brasileiro. Revista de Economia e Sociologia Rural, v.26, n.1, p.23-38, jan./mar. 1988.

PASTORE, A.C.; ALVES, E.R.A.; RIZZIERI, J.A.B. A inovação induzida e os limites à modernização na agricultura brasileira. In: Revista de Economia Rural, Porto Alegre, 1974. Anais. São Paulo, Instituto de Economia Agrícola, 1976. P.257286.

PATRICK, G.F.; KEHRBERG, E.W. Custos e retornos de educação em cinco áreas agrícolas da região leste do Brasil. In: ARAÚJO. P.F.C.; SCHUH, G.E. Desenvolvimento da agricultura: educação, pesquisa e assistência técnica. São Paulo: Pioneira, 1975. Cap. 1, 17-34: educação. 
PEREIRA, S.M. Margem de comercialização e análise de preços para alguns produtos da agricultura paulista. Viçosa, 1996. 75p. Monografia (Graduação) Universidade Federal de Viçosa.

REZENDE, G.C. A agricultura e a reforma do crédito rural. Revista Brasileira de Economia, v.29, n.2, p.185-206, abr./jun. 1985.

REZENDE, G.C. Crescimento econômico e oferta de alimentos no Brasil. Revista Economia Política, v.6, n.1, jan./abr. 1986.

SANTIAGO, F.S. A oferta agrícola brasileira: incentivos de preços e crédito de custeio. Revista Brasileira de Economia, v.41, n.3, p.323-342, jul./set. 1987.

SECRETARIA DE PLANEJAMENTO E DESENVOLVIMENTO REGIONAL / SUPERINTENDÊNCIA DE ESTATÍSTICA, PESQUISA E INFORMAÇÃO (SEPLAN -GO). Anuário Estatístico de Goiás Ano 1996 - Goiânia - GO.

SILVA, C.R.L.; CARVALHO, M.A.; ARAÚJO, P.F.C. Financiamento privado da agricultura: uma avaliação dos mercados físicos. ANPEC. Material disponível no Site: http://www.ie.ufrj.br no dia 23 de março de 1999.

SILVA, C.R.L.; CARVALHO, M.A.; MARGARIDO, M.A. e FERREIRA, C.R.R.P. O processo de modernização e o uso de tratores na agricultura brasileira. Agricultura em São Paulo. SP , 37 (3) p. 119-128, ano 1990.

SILVA, L.A.C. A função de produção da agropecuária brasileira: diferenças regionais e evolução no período 1975-1985. Piracicaba, 1996, 157p. Tese (doutorado) - Escola Superior de Agricultura "Luiz de Queiroz", Universidade de São Paulo.

SOUSA, I.S.F. Condicionantes à modernização da soja no Brasil. Revista de Economia e Sociologia Rural, v.28, n.2, p.175-212, abr./jun. 1990. 
SOUZA, M.M.C. O analfabetismo no Brasil sob o enfoque demográfico. Textos para discussão n ${ }^{\circ}$ 639. Brasília, IPEA. Abril de 1999. 26p.

TARSITANO, M.A.A. Análise da agricultura matogrossense, 1970/85: modernização, desconcentração da terra e mão-de-obra. São Paulo, 1990. 152p. Tese (doutorado) - Escola de Administração de Empresas de São Paulo, Fundação Getúlio Vargas.

THOMPSON, R.L. The metaproduction function for brazilian agriculture: an analysis of productivity and other aspectos of agricultural growth. Purdue, 1974. 177p. Tese (doutorado) - Purdue university.

TINÔCO, P.B. Influência do ensino formal na produção agropecuária. Viçosa, 1981. 75p. Dissertação (mestrado) - Universidade Federal de Viçosa.

VICENTE, J.R. Influência da educação, pesquisa e assistência técnica na produtividade da agricultura brasileira na década de setenta. Piracicaba, 1989. 193p. Dissertação (mestrado) - Escola Superior de Agricultura "Luiz de Queiroz", Universidade de São Paulo.

YOUMANS, R.; SCHUH, G.E. Um estudo empírico do mercado de mão-de-obra em um país em desenvolvimento, Brasil. In: ARAÚJO. P.F.C.; SCHUH, G.E. Desenvolvimento da agricultura: natureza do processo e modelos dualistas. São Paulo: Pioneira, 1975. 173-192p. 
APÊNDICE 
APÊNDICE 1. Municípios goianos emancipados e municípios de origem, Goiás, 1970 1992.

\begin{tabular}{|c|c|c|}
\hline Municípios & Data de Emancipação & Município de Origem \\
\hline \multicolumn{3}{|l|}{ Centro Goiano } \\
\hline \multicolumn{3}{|l|}{ Anápolis } \\
\hline Itaguari & $27-01-1988$ & Taquaral de Goiás \\
\hline Jesúpolis & 16-01-1991 & São Francisco de Goiás \\
\hline \multicolumn{3}{|l|}{ Anicuns } \\
\hline Adelândia & 27-01-1988 & Mossâmedes \\
\hline Americano do Brasil & $10-06-1980$ & Anicuns \\
\hline Buriti de Goiás & 29-04-1992 & Mossâmedes \\
\hline \multicolumn{3}{|l|}{ Ceres } \\
\hline Guaraíta & 29-04-1992 & Itapuranga \\
\hline Guarinos & $11-05-1988$ & Pilar de Goiás \\
\hline Morro Agudo de Goiás & $28-01-1988$ & Rubiataba \\
\hline Nova Glória & $10-06-1980$ & Ceres \\
\hline Santa Isabel & $14-05-1982$ & Jaraguá \\
\hline São Luíz do Norte & $28-01-1988$ & Itapaci \\
\hline \multicolumn{3}{|l|}{ Goiânia } \\
\hline Bonfinópolis & $27-01-1988$ & Leopoldo de Bulhões \\
\hline Caldazinha & 29-04-1992 & Bela Vista de Goiás \\
\hline Santo Antônio de Goiás & 05-12-1990 & Goianira \\
\hline Senador Canedo & $28-01-1988$ & Goiânia \\
\hline Terezópolis de Goiás & 29-04-1992 & Goianápolis \\
\hline \multicolumn{3}{|l|}{ Iporá } \\
\hline \multicolumn{3}{|l|}{ Leste Goiano } \\
\hline \multicolumn{3}{|l|}{ Entorno de Brasília } \\
\hline Água Fria de Goiás & $27-01-1988$ & Planaltina \\
\hline Cidade Ocidental & 16-01-1991 & Luziânia \\
\hline Cocalzinho de Goiás & 03-07-1990 & Corumbá de Goiás \\
\hline Mimoso de Goiás & $27-01-1988$ & Padre Bernardo \\
\hline Santo Antônio do Descoberto & $14-05-1982$ & Luziânia \\
\hline Vila Boa & 29-04-1992 & Formosa \\
\hline \multicolumn{3}{|l|}{ Vão do Paranã } \\
\hline Buritinópolis & 29-04-1992 & Mambaí \\
\hline Simolândia & 28-01-1988 & Posse \\
\hline \multicolumn{3}{|l|}{ Noroeste Goiano } \\
\hline \multicolumn{3}{|l|}{ Aragarças } \\
\hline Arenópolis & $14-05-1982$ & Piranhas \\
\hline \multicolumn{3}{|l|}{ Rio Vermelho } \\
\hline Araguapaz & $14-05-1982$ & Goiás \\
\hline Faina & $28-01-1988$ & Goiás \\
\hline Matrinchã & $27-01-1988$ & Aruanã \\
\hline Santa Fé de Goiás & $27-01-1988$ & Jussara \\
\hline
\end{tabular}


APÊNDICE 1. Municípios goianos emancipados e municípios de origem, Goiás, 1970 1992.

\section{São Miguel do Araguaia}

Mundo Novo

Nova Crixás

Novo Planalto

Uirapuru

Norte Goiano

\section{Chapada dos Veadeiros}

Colinas do Sul

Teresina de Goiás

\section{Porangatu}

Alto Horizonte

Campinaçu

Campos Verdes

Minaçu

Montividiu do Norte

Nova Iguaçu de Goiás

Trombas

Sul Goiano

Catalão

\section{Meia Ponte}

Cachoeira Dourada

Inaciolândia

Professor Jamil

Rio Quente

Vicentinópolis

Pires do Rio

São Miguel do Passa Quatro

\section{Quirinópolis}

Gouvelândia

\section{Sudoeste de Goiás}

Aparecida do Rio Doce

Castelândia

Chapadão do Céu

Doverlândia

Montividiu

Palestina de Goiás

Perolândia

Santo Antônio da Barra
10-06-1980

10-06-1980

27-01-1988

29-04-1992

27-01-1988

28-01-1988

16-01-1991

14-05-1982

27-01-1988

14-05-1976

29-04-1992

16-01-1991

28-01-1988

14-05-1982

29-04-1992

16-01-1991

11-05-1988

10-06-1980

28-01-1988

27-01-1988

16-01-1991

16-01-1991

16-01-1991

14-05-1982

27-01-1988

27-01-1988

16-01-1991

29-04-1992

(Continuação)

Crixás

Crixás

São Miguel do Araguaia

Crixás

Cavalcante

Cavalcante

Mara Rosa

Uruaçu

Santa Terezinha de Goiás

Uruaçu

Trombas

Mara Rosa

Formoso
Itumbiara

Itumbiara

Piracanjuba

Caldas Novas

Pontalina

Silvânia

Quirinópolis

Jataí

Rio Verde

Aporé

Caiapônia

Rio Verde

Caiapônia

Jataí

Rio Verde 
APÊNDICE 1. Municípios goianos emancipados e municípios de origem, Goiás, 1970 1992.

Vale do Rio dos Bois

Acreúna

Cezarina

Edealina

Indiara

São João da Paraúna

Turvelândia
14-05-1976

27-01-1988

27-01-1988

14-05-1982

28-01-1988

28-01-1988

(Continuação)

Paraúna

Palmeiras de Goiás

Edéia

Jandaia

Paraúna

Acreúna 